\title{
Reexamining the Measurement of Pro-Environmental Attitudes and Behaviors to Promote Sustainable Development: A Systematic Review
}

\author{
Josephat Paul Nkaizirwa ${ }^{1,2^{*}}$, Florien Nsanganwimana ${ }^{1}$, Catherine Musalagani Aurah ${ }^{3}$ \\ ${ }^{1}$ African Centre of Excellence for Innovative Teaching and Learning Mathematics and Science (ACEITLMS), College of Education, \\ University of Rwanda, RWANDA \\ 2 Department of Educational Psychology and Curriculum Studies, College of Education, University of Dodoma, TANZANIA \\ ${ }^{3}$ Department of Science and Mathematics Education, School of Education, Masinde Muliro University of Science and \\ Technology, KENYA
}

Received 15 March 2021 - Accepted 26 July 2021

\begin{abstract}
An increasing trend of environmental problems is largely associated with human interaction with nature. While individual attitudes and behavior play a pivotal role in attaining sustainable ecological actions, this article questions whether there is adequate coverage of the current environmental issues in the existing scales measuring environmental attitudes and behaviors. To achieve the United Nations sustainable development goals (SDGs), sustainable efforts need to be invested to shape human interaction with nature. Nonetheless, the question of whether an effective change in attitudinal and behavioral constructs can translate into objective ecological actions requires sound measurements. Based on an analysis of 54 scales, the present article reveals that some critical environmental issues such as climate change and inclusiveness of science and technology have largely been neglected. It further brings out a conclusion that proposes a transitional approach for environmental psychologists to rethink the measurement approaches that broadly enhances sustainable development in global terms.
\end{abstract}

Keywords: pro-environmental attitudes, pro-environmental behavior, sustainable development, environmental scale, a systematic review

\section{INTRODUCTION}

Pro-environmental attitudes (PEA) and behaviors are increasingly considered potential variables accounting for the contemporary environmental pressing issues (Clayton, 2019; Nielsen et al., 2020; Proctor \& Vu, 2019; Van Lange, Joireman, \& Milinski, 2018). While the need for conservation psychology grows immensely to address the existing environmental problems, the measurement of PEA and pro-environmental behavior (PEB) has created endless debates in psychological research (McIntyre \& Milfont, 2016). This motivated Gifford and Nilsson (2014) to note that the understanding of pro-environmental attitudes and behavior "is far more complex than previously thought". Hundreds of scales for measuring PEA and PEB are available and this makes the selection of a robust one to use in a study an overwhelming process (Cruz \& Manata, 2020). Despite the widest range of the available scales for PEA and PEB, little is known on the extent to which they address the most pressing environmental issues such as climate change, loss of biodiversity, and environmental pollution. An increasing threat from environmental problems hampers the United Nations (UN) efforts to attain sustainable development goals (SDGs) (Mensah, 2019).

The existing scales should ensure sufficient emphasis is placed on the current environmental pressing issues for enhancing sustainable development (Steg \& Vlek, 2009). The need to rethink the measurement of PEA and PEB stems from the consequential influence played by attitudes and behavior in determining the quality of the environment (Palupi \& Sawitri, 2018). To attain sustainable development (SD), the sustainable use of environmental resources becomes a necessary requirement (Maurer \& Bogner, 2019). While this is a substantial requirement in mitigating the existing environmental problems (Nielsen et al., 2020; Proctor \& $\mathrm{Vu}, 2019)$, little is known on the extent to which the current environmental pressing issues have been

(c) 2021 by the authors; licensee Modestum. This article is an open access article distributed under the terms and conditions of the Creative Commons Attribution License (http://creativecommons.org/licenses/by/4.0/).

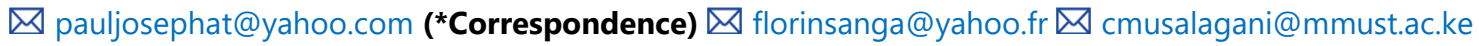




\section{Contribution to the literature}

- This article provides a systematic review on one of the potential fields of research by unpacking the extent to which the most critical environmental problems have been integrated into the existing scales of proenvironmental attitudes and behavior.

- This article provides compelling results suggesting that the existing scales have, to a large extent, neglected a considerable coverage of the most environmental pressing issues such as climate change and impacts of science and technology on the environment.

- The article calls for the need to reexamine the measurement approaches towards addressing proenvironmental attitudes and behavior to achieve sustainable development goals.

adequately addressed in the existing measurement tools of PEA and PEB.

Motivated by the social psychological theory (Krieger, Chung-Yan, \& Towson, 2017), this article presents a systematic review of the representative PEA and PEB scales and provides recommendations for future research. A scale in this context refers to a measurement tool containing a collection of items (or with a single item) for assessing environmental attributes (in this case environmental attitude, behavior, or both) that can objectively make individual comparison and help in transforming the existing individual differences on the compared attributes for environmental benefits (Kaiser, Merten, \& Wetzel, 2018). The current review aims at addressing the following questions.

\section{Article Review Questions}

1. What are the areas of environmental focus that most environmental attitude and behavior scales have primarily targeted to enhance sustainable development in contemporary contexts?

2. Reflecting on the existing environmental attitude and behavior scales, to what extent have the demographic patterns (childhood, adolescence, and adulthood) been integrated?

\section{AN ACCOUNT OF THE LITERATURE REVIEW}

\section{The Social Psychological Theory}

There are different perspectives explaining the role of attitudes and behaviors in any given society. For instance, Krieger et al. (2017) have explained three functions of a social psychological theory (SPT) about scientific research. First, it provides an organizational role to serve an investigative function and connects coherent observations into workable solutions. Second, it provides directions about where more research efforts should be directed. This is determined by cumulative evidence from the observed phenomena. Thus, according to Krieger and colleagues, SPTs may provide useful insights about the areas that have been previously neglected and therefore suggest future areas of research for hypotheses testing and for generating solutions to the existing problems. The third function of the SPTs is to guide areas that require useful interventions. That is, to promote global changes and prevent future destructions. In environmental terms, it can be summarized that SPTs determine the interrelated observed phenomena and provide systematic guidance for creating the required solutions to the existing environmental problems.

While several SPTs have explained the attitudinal and behavioral roles in shaping human actions (e.g., Festinger, 1957; Rokeach, 1967; Schultz, 2001), the present authors decided to focus on the Value-BeliefNorm (VBN) theory that supports social movements (Stern et al., 1999). The VBN theory of environmentalism postulates that perceiving adverse consequences (AC) of environmental problems activates mitigation behaviors. The VBN links value theory, the norm-activation theory (NAT), and the New Environmental/Ecological Paradigm (NEP) by proposing a causal chain of five variables mediating PEBs: personal values, personal beliefs (NEP, AC, and ascription of responsibility or AR to personal norms (PN). According to Stern (2000), awareness of the consequences arising due to failure of an individual to act reasonably activates personal norms (PN) that in turn mediates responsible actions against a future occurrence of the adverse impacts. That is, when problems are made aware to the public, the sense of obligation for the people to take environmental action is influenced and consequently, actual behaviors are more likely to be implemented. A diagrammatic summary of the VBN is presented in Figure 1.

Subsequent validation by independent cross-cultural studies have provided support for the VBN theory in understanding environmental behaviors across the world such as in Taiwan (Chen, 2015), Norway (Brende et al., 2015), Chile (Bronfman et al., 2015) as well as in China and Malaysia (Ghazali, Nguyen, \& Mutum, 2019) among other global representative studies. Likewise, a study by Zachariou et al. (2020) that was conducted in Viotia in Greece revealed that the more aware the participants they were about environmental challenges the more willing the expressed to engage in solving the existing environmental challenges. Likewise, Samputri and Safitri (2020) found the link between environmental knowledge about ecosystem, environmental pollution as 


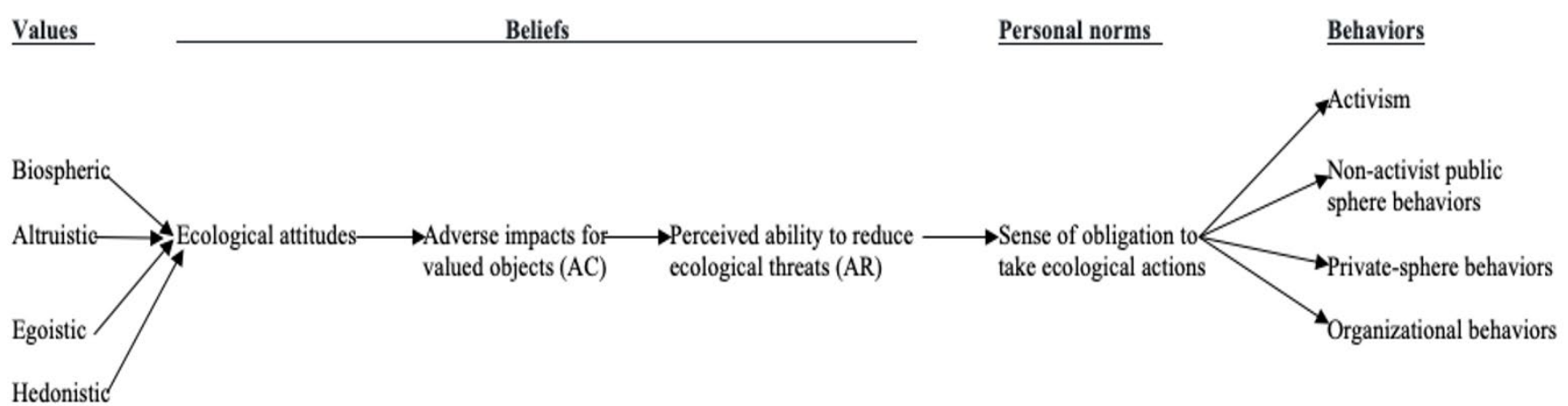

Figure 1. A combined model to explain the relationships between values, beliefs, personal norms, and ecological behaviors; the value-belief-norm theory of environmentalism

Source: Stern (2000, p. 412)

well as about environmental attitudes towards implementing eco-friendly behavior among the fishermen in Makassar, Indonesia. These findings are also coherent with those reported by Goulgouti, Plakitsi, and Stylos (2019) among the pre-service teachers at the University of Ioannina, in Greece at which environmental literacy and attitudes appeared to play a mediating role in pro-environmental behavior. Therefore, awareness of environmental consequences plays a pivotal role in ameliorating eco-friendly behaviors as hypothesized in the VBN theory (Stern, 2000).

The basic difference between NAT (Schwartz, 1977) and the VBN theory is that the former focuses on the social altruistic values or self-transcendent whereas as the latter extends by including both altruistic values and other personal values: the egoistic or self-enhancement, and biospheric values, and it also measures directly the relevant individuals' beliefs (Sawitri, Hadiyanto, \& Hadi, 2015). Nonetheless, the NAT and VBN theories share the same feature in that they are both motivationally driven models. Broadly, the VBN realizes how individual personal interests (ego), sense of environmental concern (biospheric), and caring for other people (altruistic) can interrelate to shape one's behavior when interacting with the environment.

On the contrary, the theory of planned behavior (TPB) focuses on rational choices as an influencing factor for individuals to act ecologically (Ajzen, 1991). Ajzen argues that intention to perform different kinds of behavior are mediated by attitudes, subjective norms, and perceived behavioral control. A combined effect of intentions with perceptions of behavioral control is responsible for differences in performing demonstrable behavior among individuals. This rational model stems from self-interest as an important determinant of behavior as opposed to the NAT and the VBN theories (Bamberg \& Möser, 2007). Ajzen concludes by noting that the exact relations between attitudes towards behavior and between other explained constructs of subjective norms, normative beliefs, and perceived control of behavior are incomprehensively represented.
The TPB and the VBN theories share a common explanation in that they both view behavioral norms as determinants of intentions that in turn predict relevant environmental behavior (Sawitri et al., 2015).

The present authors chose to focus on the VBN theory because; first, it is a robust model that has broadly explained the interaction between attitudes and behavior and it coherently connects other theoretically sound models such as value theory, NAT, NEP, and TPB in simpler and clearer approach (Stern, 2000). Second, it explains psychological (e.g., personal norms) and other contextual factors (e.g., economic, socio-cultural, technological factors) in understanding human behavior (Stern et al., 1999). Third, it provides a comparable classification of environmental behavior and the mediating factors behind them (Chen, 2015). It is believed that these factors provide convincing evidence for explaining what shapes sustainable actions to promote SD.

\section{Environment and the Sustainable Development Context}

Historically, SD has gone through three major phases: the first phase was in 1972 when the first world summit of the environment was held in Stockholm, Sweden with a major emphasis on human and environment by prioritizing changes in environmental management policy among the countries as they struggled to attain economic growth (Schmuck \& Schultz, 2003). The second phase involved the World Commission on Environment and Development (WCED) in 1987 when SD was defined as "development that meets the needs of the present without compromising the ability of future generations to meet their needs" (WCED, 1987, p. 43). However, this definition has been criticized for being too general on human beings with a limited understanding of what constitutes the current and future needs (Schmuck \& Schultz, 2003). Alternatively, Schmuck and Schultz proposed a more robust definition that integrates "social and economic changes that are necessary to approach ecological stability" (p. 6). Notwithstanding, the 
proposed definition neglects the inclusion of governance that has recently become an integral component of SD pillars (Shi et al., 2019). Moreover, energy and environmental resources were considered inadequate to support the increasing population, hence necessitating the need to protect them.

In the third phase of SD, the UN held another conference in Rio de Janeiro, Brazil in 1992. The outcomes of which approved the "Rio Declaration on Environment and Development" as well as the "Agenda 21" (UN, 1992). Likewise, the developed and developing countries discussed an agreement on the identification of the common but differentiated responsibilities. Among the agreed objectives, included the technology transfer from the developed to developing nations as one of the means to curb environmental challenge impacts.

On the other hand, the UN millennium summit that was hosted in New York reexamined the successes of the previous agreements. Subsequently, the outcomes from 189 representatives adopted the UN Millennium Declaration that set the Millennium Development Goals (MDGs). Primarily, the MDGs focused on the development and elimination of extreme poverty by targeting eight priority areas as goals and 21 operational targets. Besides, SD pillars were extended from three to four pillars in 2012 through the UN Rio+20 summit to include governance. Relatedly, a green economy was identified as a solution towards mitigating the conflicts between development and the environment (UN, 2015). As of recent, the UN conference held another assessment conference in New York in 2015 to assess the implementation of MDGs. More than 150 heads of states adopted the 2030 agenda for SD as guidance and framework for global developmental and environmental matters for 15 years. Generally, the conference approved 17 goals and 169 operational targets. The identified goals cut across four broad focus areas including society (goals $1,3,4,5,11$, \& 16), environment $(2,6,7,13,14$, \& 15), economy (goals 8, 9, 10, \&12), and governance-goal 17 (Shi et al., 2019). Figure 2 provides a diagrammatic summary of the mutual relationships among the SD pillars.

With reference to Figure 2, Stern (2000) has explained four determinants of ecological actions that include attitudinal (e.g., norms, beliefs, values) factors, personal abilities (e.g., the expertise required for a given ecological action, sociodemographic factors), contextual or external influences (e.g., community expectations, political regulations or government influences, monetary incentives), and habit or routines. Each of the SD pillars indicated in Figure 2 plays an important role in shaping the environment. Double-headed arrows communicate a two-way influence in which exclusive mutual benefits or negative impacts can be shared between the environment and other associated SD pillars. It should be noted, however, that Figure 2 provides a representative mutual interaction but does not provide exhaustive information regarding each SD pillars. We explain this interaction in detail in the section related to human-induced environmental deterioration.

Generally, it is imperative to note that global societies have not experienced similar situations in going through the transformations of SD phases. In support of this contention, Shi et al. (2019) note that there have been some disagreements between the developed and developing nations on what needs to be prioritized. While the developed countries were more concerned with environmental priorities, the developing nations had a priority on poverty reduction issues. This variation has also been reflected in some of the empirical studies (e.g., Ogunbode, Henn, \& Tausch, 2018; Petegem \& Blieck, 2006) indicating a more exploitative perspective of environmental resources in developing than in developed countries. Yet, the majority of the existing scales for measuring EA and PEB have been developed and widely tested in the developed countries than in the developing ones (McIntyre \& Milfont, 2016).

\section{Pro-environmental Attitudes and Behaviors in Context}

To address the current environmental problems, it is necessary to understand what drives individuals to (not) act ecologically (Milfont, 2012). In operational terms, there is no single way of defining pro-environmental attitude. However, in its broad context, it can be described as the personal preferences in the preservation and utilization dimensions of the environment (Gifford \& Sussman, 2012; Milfont \& Duckitt, 2006; Wiseman \& Bogner, 2003). The preservation and utilization of environmental resources are mediated by several factors as described in the previous section. The diversity in influential factors accounts for the differences in the ways we value and appreciate the environment (Stern, 2000).

Just like pro-environmental attitudes (PEA), proenvironmental behavior (PEB) bears several definitions, all of which, aim at communicating a unique message focusing on individual actions accounting for the protection and conservation of nature (Kurisu, 2015). In literal context, examples of PEB imply individual actions that add value to the environment such as tree planting or practices that aim at reducing environmental loads such as walking or biking instead of driving to reduce greenhouse gas emissions (Nielsen et al., 2020). Nevertheless, understanding what shapes PEA and PEB remains inconclusive (Gifford \& Nilsson, 2014). The lack of a definitive conclusion on what drives people to (not) act ecologically allows a continuous debate including the ones focusing on sound scales for understanding PEA and PEB. As a result, the growing population and dynamic cultural contexts press the need for reexamining how PEA and PEB should be measured (Ripple et al., 2017). 


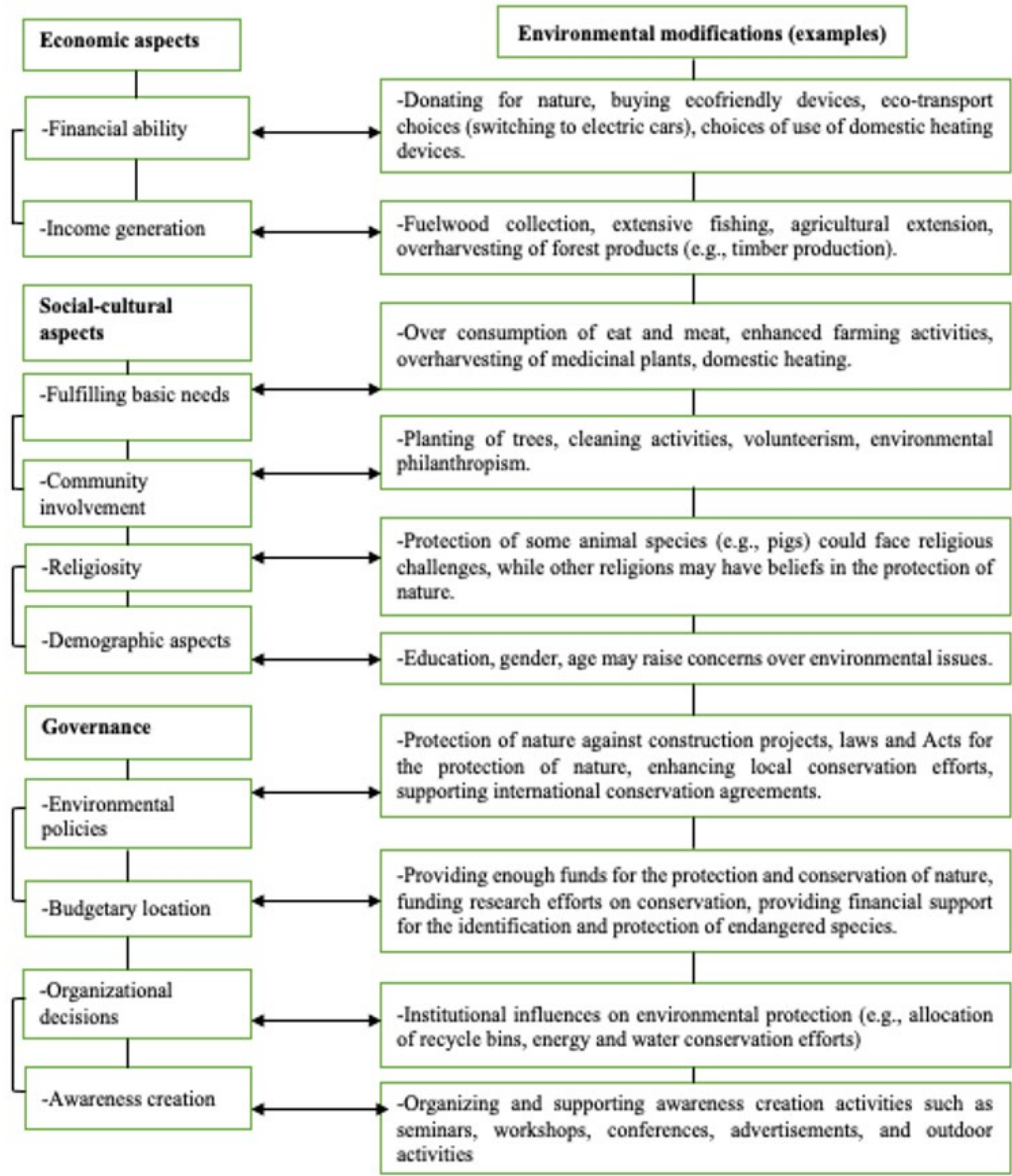

Figure 2. A summary of the interaction between SD pillars; economy, society, environment, and governance Source: Contextualized by authors based on various sources of the current literature

One among the critical concerns is a trend of population growth that continues to attract debates on how individual differences can be well integrated to ensure sustainable use of environmental resources in the struggle to attain SD (Mensah, 2019). As debates continue to capitalize among researchers, the concepts of environmental sustainability and SD have become popular in the current literature particularly after the United Nations Brundtland's report (WCED, 1987). Environmental sustainability is historically prominent from its early application in the context of German forestry (Schmuck \& Schultz, 2003) to the most current application in the context of SD (Shi et al., 2019). As such, the context of SD that integrates society, environment, economy, and governance can hardly be discussed in the exclusion of human behaviors in interaction with the environment (Shulla et al., 2020).

Indeed, as the population growth continues, increased interaction between humans and the environment continues as well. Individual attitudes and behavior have been described as the potential determinants of environmental quality (Palupi \& Sawitri, 2018). The confidence to rely on human attitudes and behavior as important determinants environmental 
quality stems from previous research as prominent scholars have imposed (Green et al., 2015). Although the focus of the present article is not on the exclusive discussion of the determinants of PEA and PEB, a detailed discussion on influential factors can be independently assessed (e.g., Bamberg \& Möser, 2007; Gifford, 2011; Hines, Hungerford, \& Tomera, 1987; Zmami \& Ben-Salha, 2020). This said, understanding human-induced actions with which environmental deteriorations are determined is of useful consideration because "individuals and societies cause and bear the consequences of conservation challenges and are fundamental to solutions" (Wallen \& Landon, 2020, p. 1340).

\section{Human-induced Activities Play the Most Significant Roles}

Theoretical and empirical evidence has supported a causal link between human actions and environmental deterioration (Steg \& Vlek, 2009). For example, analysis on the drivers of deforestation and forest degradation within the 46 developing countries by Hosonuma et al. (2012) found that commercial and substance agriculture were the leading human-driven factors. In their analysis, Hosonuma and colleagues included timber production and logging, fuelwood and charcoal production, uncontrolled wildfire, and livestock grazing as additional driving activities for environmental deterioration. Likewise, Sedano et al. (2016) found a link between charcoal production and forest degradation in Mozambique. Relatedly, a comprehensive report by the Food and Agriculture Organization of the United Nations (FAO, 2020) drew the same observations. In particular, the $\mathrm{FAO}$ report notes that agriculture alone accounts for $73 \%$ of deforestation worldwide while livestock activities occupy $30 \%$ of the terrestrial land surface (Gifford \& Chen, 2017) and contributes to $18 \%$ of the carbon dioxide $\left(\mathrm{CO}_{2}\right)$ emitted worldwide per year (FAO, 2006).

Based on the above, the situation is not only critical in developing regions such as Africa where $80 \%$ of the population in urban depends mainly on charcoal as a source of energy (Zulu \& Richardson, 2013), but also covers the global scale. At the global level, 880 million people depend on fuelwood collection or charcoal production both as a source of energy and for income generation (FAO, 2020). On the other hand, Yu et al. (2020) reported that uncontrolled wildfire has led to the loss of 2.7 million hectares (ha) of land in Australia since September 2019 approximated to three times larger than the lost area in Amazon within the same duration (906 000ha). If this trend continues, nearly $50 \%$ of the forest biodiversity is vulnerable to extinction (Lizundia-Loiola, Pettinari, \& Chuvieco, 2020). Furthermore, FAO reports that $18 \%$ ( $8 \%$ of forest plants, $5 \%$ of forest animals, and $5 \%$ of fungi) of the assessed species have been listed as critically endangered species that need attitudinal and behavioral interventions in favor of their protection.

The need to re-emphasize on the measurement of PEA and PEB is motivated by the promising evidence reported by earlier scholars. For example, Green et al. (2015) projected that GHGs emissions could be reduced by nearly $40 \%$ just by changing the consumption behavior of substituting meat and milk with plant-based foods such as fruits and vegetables. Interestingly, if the same model is adopted worldwide, it can offer a reduction of not only $15 \%$ of GHGs emissions (Poore \& Nemecek, 2018) but also a reduction of the climate change mitigation cost by 50\% (Stehfest et al., 2009). While $30 \%$ of the GHGs emission in Europe is linked to transport use, the switching to eco-friendly transport can offer significant impacts on the climate change mitigation and improving individual health status (Ivanova et al., 2017).

Collectively, the existing environmental problems are closely related to the way people interact with the environment (Lange \& Dewitte, 2019). Yet, the human population keeps growing over the available scarce resources (Mkonda \& He, 2017). The need to control human-nature interaction becomes crucial as the growing attention to integrate psychological research in solving environmental problems has become popular (Proctor \& Vu, 2019). Nonetheless, the existing scales for measuring PEA and PEB have not been unfolded on the extent to which they address the most environmental pressing issues. In agreement with the VBN theory of environmentalism, the article argues that individuals' decisions and their engagement in environmental protection and conservation preferences are largely dictated by their awareness of the environmental advance impacts that influence their sense of obligation to act against environmentally destructing habits (Stern, 2000). Therefore, unpacking what needs to be reemphasized in the measurement of PEA and PEB is one of the critical areas of current research that necessitating the present article.

\section{METHODOLOGY}

The present article adopts a systematic review in which well-defined questions, a thorough quality check of the relevant studies as well as advanced criteria for inclusion and exclusion of sampled articles have been considered for a review process (Grant \& Booth, 2009; Khan et al., 2003). Whereas the inclusion of the controlled studies in a systematic review is critical for quality purposes, Brettle (2009) recommends an alternative means in which a range of studies with heterogeneous features integrating qualitative and quantitative designs can be used to provide more useful information. In this case, a comprehensive analysis and summarized results are generated for clarity and the future progress of research in the area of the question 
under the review. Therefore, the systematic review provides detailed information that can easily be replicated by other subsequent studies. Hence, relevant for the present article.

To obtain a relevant list of articles in which the available pro-environmental attitude and behavior scales were published, recommended criteria were used. To begin with, systematic searching of the available articles using relevant keywords was employed. Specifically, the keywords included; environmental attitudes, pro-environmental attitudes, ecological attitudes, pro-environmental behavior, ecological behavior, environmental significant behaviors, environmentally friendly behavior, pro-environmental actions, and environmental concerns (Kurisu, 2015). Related keywords for mediating factors of PEA and PEB were also used. Such mediating factors included but not limited to internal factors such as psychological determinants (e.g., personality), gender, values, intentions, and norms (Ajzen, 1991; Gifford \& Sussman, 2012) as well as external/contextual determinants such as socioeconomic status (Tonglet, Phillips, \& Read, 2004), organizational structure (Ruepert et al., 2016), cultural orientations (Milfont, Duckitt, \& Cameron, 2006), education (Karpudewan, Ismail, \& Roth, 2012), and individual connectedness with nature (Richardson et al., 2019) among others.

To obtain the required articles for systematic review, data were retrieved by typing keywords in Education Resources Information Center (ERIC), Google Scholar, different journals' repositories, and ProQuest environmental education. For a retrieved article to be considered for analysis, first; the scale had to be available in an English version within the published article(s) of internationally acceptable standards (e.g., indexed in Scopus or Web of Science). Second; the scale had to be validated through clearly stated rigorous procedures in more than one study and, at least, employed by some other subsequent researchers in other different samples. This excluded scales with unclear psychometric features (e.g., Rossano, Roselli, \& Calvano, 2017) and all other scales in unpublished works such as theses or dissertations (e.g., Milfont, 2007) and conference proceedings. Third; an article had to be primarily focusing on PEA, PEB, or other related constructs such as environmental identity (e.g., Clayton, 2003), and environmental concern (e.g., Bohlen, Schlegelmilch, \& Diamantopoulos, 1993; Schultz, 2000; Weigel \& Weigel, 1978). For historical and for cumulative evidence, retrieved articles were not restricted to their duration of publication.

For quality check, the retrieved articles were scrutinized for authenticity and academic rigor by considering their publications in journals indexed in internationally recognized indexing agents such as Scopus or Web of Science. To accomplish this task, journal ranking websites such as https:/ / www.scimagojr.com/ and https://www.scilit.net/statistic-journal as well as indexing websites such as https://mjl.clarivate.com/search-results and https://www.scopus.com/home.uri and http:/ / ssci.isi-database.org/ for Social Science Citation Information (SSCI) were used. Specific journals for publishing environmental education or more specifically environmental psychology content were considered. These included but not limited to; the Journal of Environmental Education, Environment and Behavior, Journal of Environmental Psychology, Environmental Education Research, Australian Journal of Environmental Education, Personality and Individual Differences, American Psychologist, European Psychologist, Journal of Cleaner Production, Current Opinions in Environmental Sustainability, and Sustainability, among others.

Given the above, 113 documents (102 journal articles and 11 dissertations) were retrieved. All the dissertations were removed from the list for reasons mentioned earlier. Further screening for 102 remaining journal articles excluded 42 documents that did not have a primary objective of the scale development despite their content being within the required focus of the present article. Five more articles were excluded from the list for the lack of rigorous validation process to support the psychometric stability of the published scales whereas two other articles were removed from the list for the journals in which they were published were not among the list of the internationally peer-reviewed journals. Finally, $53(46.9 \%)$ of the total retrieved articles were retained and considered for further analysis. Of all the retained articles, one of them had two scales published together. Therefore, 54 scales were systematically reviewed.

For ease of analysis, variables were created in a Statistical Product and Service Solution (SPSS version 25) software. These variables included climate change, science and technology, littering and recycling, forestry, protection and conservation of biodiversity, utility saving, and environmental pollution. The authors decided to focus on these variables as they have been consistently cited as the critical environmental pressing issues raising threats to sustainable living (Mensah, 2019; Ripple et al., 2017; Williams, Balmford, \& Wilcove, 2020). Broadly, these critical issues are hereafter regarded as the first category in the classification of variables. Additionally, some other focus areas beyond the critical areas were included in the first category. To be precise, this category included items with no specific environmental focus termed in this article as general environmental focus. Sample items and the selection criteria for each variable are detailed in Table 1.

For the first category, the actual number of items for each variable was entered within the SPSS software. On the other hand, a second category for scale items whose 
Table 1. Systematic review of items selected and grouping criteria

\begin{tabular}{|c|c|c|}
\hline Area of focus & Nature of the considered items & Sample items \\
\hline Climate change & Items focusing on climate change debates & $\begin{array}{l}\text { "The world climate will probably massively change if } \mathrm{CO}_{2} \\
\text { continues to be emitted into the } \\
\text { atmosphere in as huge amounts as it is now" (Kaiser, Wolfing, \& } \\
\text { Fuhrer, 1999, p. 9). }\end{array}$ \\
\hline $\begin{array}{l}\text { Littering/ } \\
\text { recycling }\end{array}$ & $\begin{array}{l}\text { Items that emphasize on management or } \\
\text { treatment of wastes. }\end{array}$ & $\begin{array}{l}\text { "I collect and recycle used papers" (Kaiser, Oerke, \& Bogner, } \\
2007 \text {, p. 246). }\end{array}$ \\
\hline Forestry & Items focusing on vegetation cover. & $\begin{array}{l}\text { "We need to clear forests in order to grow crops" (Bogner \& } \\
\text { Wiseman, 2006, p. 251). }\end{array}$ \\
\hline Biodiversity & $\begin{array}{l}\text { Items related to sensitizing on species } \\
\text { diversity. }\end{array}$ & $\begin{array}{l}\text { "Saving threatened species in unnecessary luxury" (Blok et al., } \\
2015, \text { p. 10). }\end{array}$ \\
\hline
\end{tabular}

Pollution Items related to the addition of unrequired "I would be willing to write letters asking people to help reduce materials to the environment. $\quad$ pollution" (Leeming, Dwyer, \& Bracken, 1995).

Technology Items related to the use of information and "Technology can overcome any environmental problems" (Trobe communication technology or related \& Acott, 2000, p. 16).

devices such as mobile, TV, computers, etc.

Utility saving Items emphasizing on protection and The effect of water consumption on the future of the planet and conservation of scarce resources such as for future generations is exaggerated" (Félonneau \& Becker, 2008, water and power/energy saving. $\quad$ p. 51).

General focus Items focusing on the environment as "I rarely think about these environmental changes" (Homburg, general without specific environmental Stolberg, \& Wagner, 2007, p. 961). discipline.

Minority group Items are sensitive to marginalized groups. "I do not buy products from companies that I know use sweatshop labor, child labor, or other poor working conditions" (Sudbury-Riley \& Kohlbacher, 2015, p. 7).

Gender Gender-sensitive items.

"In the past, I have not purchased a product because its advertising depicted women in a negative way" (Roberts, 1995, p. 105).

Regional Items with a regional-specific focus.

"I do not buy products from companies who have investments in South Africa" (Roberts, 1995, p. 105).

Green Items with a specific focus on the

"For shopping, I prefer paper bags to plastic ones" (Kaiser, 1998, consumerism purchase, use, and disposal of eco-friendly p. 405). materials.

Environmental Items focusing on sensitizing movements activism for ecological actions (e.g., donating for nature, support for ecological protection policies)
"I sign petitions supporting nature conservation effort" (Barbett, Stupple, Sweet, Schofield, \& Richardson, 2020, p. 8).

"I contribute financially to environmental organizations" (Kaiser, Hartig, Brügger, \& Duvier, 2011, p. 381)

"I would be willing to pay much higher taxes to protect the environment" (Stern, Dietz, \& Guagnano, 1998, p. 993).

"The government policies developed to deal with the environmental situation are excellent" (Pelletier, Legault, \& Tuson, 1996, p. 12).

"Humans have the right to modify the natural environment to suit their needs" (Dunlap et al., 2000, p. 433).

Industria

activities

Enjoyment of nature

Ecological

knowledge

Social altruistic

Dishonest
"When I think of the ways industries are polluting, I get frustrated and angry" (Maloney, Ward, \& Braucht, 1975, p. 788).

Items that focus on industrial issues.

Items focusing on an individual's affection towards the environment. time outdoors "communing with nature" (Clayton, 2003, p. 61).

Items related to information sharing and "I want to engage in changing society towards sustainable promoting an improved ecological literacy. development" (Olsson et al., 2020, p. 8).

Items with a specific focus on caring for "I am concerned about pollution because of the consequences for others' needs.

other people" (Bruni, Chance, \& Schultz, 2012, p. 5).

Items with a specific focus on misconduct
"Sometimes I ride public transportation without paying a fare" (Kaiser, 1998, p. 404). 
Table 2. Summary of the scales' items and their focus areas on critical environmental issues

\begin{tabular}{|c|c|c|}
\hline Focus areas of the scales' items & Number of items & Percent \\
\hline Climate change (e.g., reduction in GHGs emission) & 31 & 2.1 \\
\hline Littering/Recycling (e.g., paper management) & 154 & 10.6 \\
\hline Forestry (e.g., sensitivity to vegetation cover) & 57 & 3.9 \\
\hline Biodiversity (e.g., taking care of animals) & 153 & 10.5 \\
\hline Environmental pollution (e.g., chemical spilling) & 211 & 14.5 \\
\hline Science and technology (e.g., confidence in technology) & 33 & 2.3 \\
\hline Utility saver (e.g., water, energy) & 153 & 10.5 \\
\hline General environmental focus & 666 & 45.7 \\
\hline Total number of items & 1458 & 100.0 \\
\hline
\end{tabular}

Note: GHGs=Greenhouse gases

Table 3. Scales' items focus areas other than the main global critical issues

\begin{tabular}{lccc}
\hline \multirow{2}{*}{ Specific environmental targets } & \multicolumn{2}{c}{ Responses } & \multirow{2}{*}{ Percent of cases } \\
\cline { 2 - 4 } Minority groups & $\mathrm{N}$ & Percent & 3.8 \\
Green consumerism & 2 & 1.8 & 26.9 \\
Ecological knowledge & 14 & 12.5 & 44.2 \\
Environmental activism & 23 & 20.5 & 69.2 \\
Industrial activities & 36 & 32.1 & 3.8 \\
Enjoyment of nature & 2 & 1.8 & 28.8 \\
Anthropocentrism & 15 & 13.4 & 25.0 \\
Prosocial actions & 13 & 11.6 & 11.5 \\
Dishonest & 6 & 5.4 & 1.9 \\
Total & 112 & 0.9 & 215.4 \\
\hline
\end{tabular}

contents were beyond the first category, multiple response categories were created. In particular, a coding system with two values ( 0 for the absence of the variable, 1 for the existence of the variable) was used. It should be noted, however, that in this second category, the actual number of items was not used to avoid duplication of data. Notwithstanding, the second category serves to provide supplementary information beyond that specified in the first category to maximize the exhaustive availability of data contained within each of the analyzed scales. Yet, it is possible, for example, an item to focus on environmental pollution while it also addresses environmental activism (e.g., writing a letter to an industry that pollutes the environment) in the second category (Stern, 2000).

\section{RESULTS}

In total, 54 scales comprised of 1458 (mean=27.0, $\mathrm{SD}=22.3$ ) items were analyzed. Moreover, as depicted in Table 2, it was observed from the present review that more items (666 out of 1458 or $45.7 \%$ ) within the analyzed scales did not have a specific environmental target in their content. Thus, the content within such items does not specifically focus on a respective environmental aspect. They, instead stress on the general environment as a whole (e.g., I care about environmental issues). Strictly speaking, climate change that has received popularity as one of the critical environmental problems (e.g., Ghazali, Nguyen, \& Mutum, 2019; Polasky et al., 2019; Taufique et al., 2016) seems to have been neglected in the existing scales (only 31 of 1458 items or $2.1 \%$ ) of both pro-environmental attitudes and behavior. Considerable attention has largely been given to issues related to environmental pollution (211 of 1458 items or $14.5 \%)$, littering and recycling (154 of items or $10.6 \%)$, biodiversity (153 items or $10.5 \%$ ), and utility saving (153 items or 10.5\%) among others (review question 1).

Apart from the critical environmental issues that fall in the first category as noted earlier, the second category as indicated in Table 3, was widely represented by items focusing on environmental activism (69.2\%), enhancing ecological knowledge $(44.2 \%)$, enjoyment of nature $(28.8 \%)$, green consumerism (26.9\%), and anthropocentrism (25.0\%). Environmental activism includes ecological actions such as donating for nature, support for environmental policies (e.g., increasing tax for car parking), boycotting non-ecological organizations, and active participation in environmental activities such as community engagement in tree planting among others (Stern, 2000).

Regarding demographic patterns (question 2), at least, each inhabitable continent was represented (Table 4) from which the scales were developed and validated for the first publication. The results indicated that Europe and North America occupy the largest (46.3\% and $44.4 \%$, respectively) representativeness over other continents. Demographically, the majority of the analyzed scales have been developed for adults (42 of 54 or $77.8 \%$ ) particularly over the mean age of 20 years or higher. A few of the analyzed scales were primarily developed for children (7 of 54 or 13.0\%), and adolescents ( 4 of 54 or $7.4 \%$ ) in their initial development stages for the first publication. In this case, one scale was 
Table 4. Demographic data on the analyzed scales

\begin{tabular}{lcc}
\hline Developed and validated in; & $\mathrm{N}$ & Percent \\
\hline Europe & 25 & 46.3 \\
North America & 24 & 44.4 \\
Oceania, South America, and Africa & 1 & 1.9 \\
Europe and Asia & 1 & 1.9 \\
Asia & 3 & 5.6 \\
Total & 54 & 100.0 \\
\hline Developed for; & & 77.8 \\
Adults & 42 & 13.0 \\
Children $(<13$ years old) & 7 & 7.4 \\
Adolescents $>12<20$ years old) & 4 & 1.9 \\
Children and adults & 1 & 100.0
\end{tabular}

Note: <=Less than; >=greater than; $\mathrm{N}=$ Number of scales

initially developed and validated in both children and adults $(1.9 \%)$. It is worth noting, however, that subsequent cross-cultural validations to support initial development have been conducted for all the analyzed scales, and this, provides support for their psychometric stability across nations.

Despite a tremendous growth of science and technology in explaining human interaction with nature (Voulvoulis \& Burgman, 2019), psychological researchers have, to a large extent, neglected the inclusion of its content during the development and validation of environmental scales for the measurement of PEA and PEB as only 33 items (2.3\%) in the analyzed scales focused on science and technology (Table 2).

Generally, the snapshot of the present systematic review reveals that the measurement of PEA and PEB is unequally represented in the current literature suggesting that the least developed regions such as Africa and Latin America are comparatively narrowly studied compared to Europe and North America. On the other hand, the present results suggest the need to reemphasize the measurement of environmental aspects that extend inclusion of science and technology as well as climate change debates with a particular focus on grooming children's and adolescents' ecological attitudes and behaviors during the development and validations of PEA and PEB scales.

\section{DISCUSSIONS}

The present article aimed at reviewing whether the existing pro-environmental attitude and behavior scales have adequately covered the critical environmental problems. The findings from systematic review revealed that the most pressing environmental problems including climate change and integration of science and technology in environmental education have been, to a large degree, neglected by environmental psychologists in the existing scales. In reference, Van Lange, Joireman, and Milinski (2018) argue that psychological science can be used to curb the impacts of climate change only if society realizes its importance and prioritize it in policy issues relating to climate change. Likewise, Gifford (2011) identifies seven psychological limitations (dragons or inactions) for climate change mitigation in which environmental attitude becomes a potential integral component. Using cross-cultural evidence, Bain et al. (2016) argue that increasing co-benefits of economic development and community character could activate people to behave ecologically to curb the climate change driving forces. Realizing the vibrant role of psychological science in climate change mitigation necessitates a need to rethink a new approach for the climate change measurement among researchers.

Furthermore, science and technology have become inclusive components in debates of human interaction with nature (Voulvoulis \& Burgman, 2019). An exclusive discussion on how to address environmental problems can hardly be isolated from science and technology. As maintained by Nielsen et al. (2020), technology has increasingly become integrated into our everyday life. For instance, GHG emission from refrigerators is an outcome of science and technological innovation. As Nielsen and colleagues recommend, for longer-term impacts, replacement of environmentally destructive devices requires collective working between technology engineers, applied and psychological scientists who can work collectively to design and develop eco-friendly technology to enhance environmental sustainability and SD. Conversely, this effort could be meaningless if there are no robust scales that can correctly address what people think, prefer as well as perceive technology use and its related environmental consequences. As Stern (2000) posits, awareness of the adverse impacts becomes a primary determinant for people to engage in certain behavior. Likewise, reemphasizing science and technological content within the scales could be a way towards promoting behavioral change in the community.

Another interesting finding dwells on demographic variations in the ways they have been represented in the existing scales. While more scales seem to be focusing on adults, environmentalism is mediated differently by various levels of individuals in a given population 
(Gifford \& Sussman, 2012). In their longitudinal study to examine how children's environmental attitude and behavior develop, Otto et al. (2019) found that environmental attitude and behavior start to form at around the age of seven years and continues to rise to the age of 10 years where it drops until the age of 14 years. Whereas PEA was found to be fairly undeterminable through early adulthood, PEB starts to form from childhood to early adolescence and capitalizes at the age of 10 years. This growth pattern to the development of PEA and PEB underscores the need for more specific scales when measuring human interaction with nature particularly in children and adolescents who have received less consideration in the existing scales as compared to adults.

In connection to the above, there is empirical evidence indicating demographic variation between how private and public sphere environmental behaviors are implemented. For example, private-sphere behaviors such as littering and recycling as well as utility saving seem to be higher in girls/women than in men/women (e.g., Gibson, 1994; Stern, 2000). On the contrary, publicsphere behaviors such as donating for nature, support for environmental policy, and boycotting products that are not eco-friendly seem to be more prevalent in adults and in wealthier people than in young people and low earners (Duggan et al., 2004; Milfont et al., 2017). Hence, scale development needs a realistic representation that reflects heterogeneous features of the parent population including a sample with different ages, sex, education levels, socio-demographic variations as well as cultural diversity. This is important due to variations in dimensions representing people's backgrounds as seen in Milfont et al. (2020). Therefore, future scale development may benefit from a representative sample of less represented regions such as Africa, Latin America, and other low-income regions that seem to be comparatively underrepresented.

The overreliance on western-based scales may neglect major environmental challenges, such as charcoal and firewood collection, that are common in less developed countries such as Africa than in developed countries (Chidumayo \& Gumbo, 2012). A neglected focus on such critical environmental issues may deny the opportunity for public awareness (ecological knowledge) and, in turn, may lead to their limited knowledge of the adverse consequences of their environmental actions. As Venter et al. (2016) have indicated in their review, there is a higher tremendous increase of ecological footprints in lower-middle-income than in high-income countries. Since there is variation in the way people in the low-income countries interact with the environment as compared to those in industrialized countries (Petegem \& Blieck, 2006), context-specific scales could be of useful consideration in subsequent research. This also fits accurately when the environment is contextualized in terms of SD (Corral-verdugo \& Armendáriz, 2000).

\section{CONCLUSIONS}

The measurement of pro-environmental attitudes and behavior has been widely documented. Hundreds of scales for this topic have been developed and validated (Cruz \& Manata, 2020; McIntyre \& Milfont, 2016). However, looking for a single robust scale to use is overwhelming (Lange \& Dewitte, 2019). Given the impacts that human-nature interaction poses, it becomes inevitable to rethink the new approaches that integrate a comprehensive diversity of the contemporary environmental pressing issues. Notwithstanding, awareness of the impacts that the present environmental problems pose is one of the critical areas of research. To embark on this important topic, robust models such as the VBN with widely acceptable features, provide compelling explanations over other models (Stern, 2000; Stern et al., 1999). The existing scales seem to have given considerable attention to private-sphere behaviors such as littering and recycling, utility saving, and consumerism among others. On the contrary, public sphere behaviors to address the most challenging issues such as climate change as well as impacts of science and technology have been largely neglected. Likewise, the existing scales have largely focused on measuring environmental attitudes and behaviors of adults with limited consideration of children and adolescents.

\section{SIGNIFICANCE AND IMPLICATION}

Our findings provide useful insights for future research particularly on the areas that need re-emphasis when measuring pro-environmental attitudes and behavior. This is important as integrating psychological research in addressing the existing environmental problems has received considerable attention (Nielsen et al., 2020; Proctor \& Vu, 2019). That is, the need to reexamine the way attitudes and behavior are currently measured is critical and useful to address the existing environmental challenges. Future research on the measurement of environmental attitudes and behavior should specifically provide adequate emphasis not only on climate change that has received limited attention but also, they should as well press considerable emphasis on the integration of science and technology whose impacts on environmental aspects have become popular in human-nature relations (Voulvoulis \& Burgman, 2019).

\section{LIMITATIONS AND SUGGESTIONS}

Although remarkable, our findings could be questioned particularly on the classification of the most pressing environmental issues. While climate change seems to be ignored in most of the scale items, it could be difficult to trace its indirect measurement through items such as those measuring environmental pollution, 
transport choices, or application of alternative energies. Strictly speaking, our interpretation of climate change is based on items that mentioned issues of carbon emissions or climate change per se. This draws attention to the difficulty imposed in putting a clear cut between climate change and other environmental challenges such as ozone layer depletion, air pollution, limiting beef or pork consumption, or any other related issues. It seems that the accurate interpretation remains in the intention of the research when administering the items.

In other words, an item that measures air pollution in terms of limiting private car use could also be useful in estimating climate change impacts or estimating species extinction due to pollution impacts, and the contribution of technology in environmental footprints (Voulvoulis \& Burgman, 2019).

Another limitation is the replicability of some items from the original scales to subsequent application, modification, or development of new scales with minor modification of the original items. The screening of subsequent duplication of original scales' items is next to impossible following the existence of hundreds of scales existing with minor changes to the original items. In this systematic review, each scale was treated as a new and independent one in terms of contribution to the quantification of the item pools and categorization used in the analysis. Therefore, related items that appear on more than one scale have been treated independently and we believe that this has not altered the primary objectives at hand.

On the other hand, Steg and Vlek (2009, p. 311), revealed that VBN theory appears to be far more relevant in explaining; "low-cost environmental behaviors' and 'good intentions' such as willingness to change behavior, political behavior, environmental citizenship, or policy acceptability, but they appear to have far less explanatory power in situations characterized by high behavioral costs or strong constraints on behavior, such as reducing car use." This quotation aligns with what Stern (2000) as well as Gifford and Sussman (2012) have pointed indicating that there is no single theoretical model that can provide a comprehensive understanding of environmental attitudes and behavior. Thus, individual environmental actions are determined by multiple factors that cannot be explained in a single theoretical perspective. Likewise, the findings in the present paper could serve contextspecific explanations rather than general explanations of the overall global challenges pertaining to PEA and PEB.

Author contributions: All authors have sufficiently contributed to the study, and agreed with the results and conclusions.

Funding: No funding source is reported for this study.

Declaration of interest: No conflict of interest is declared by authors.

\section{REFERENCES}

Ajzen, I. (1991). The theory of planned behavior. Organizational Behavior and Human Decision Processes, 50(2), 179-211. https://doi.org/10.1016/ 0749-5978(91)90020-T

Bain, P. G., Milfont, T. L., Kashima, Y., Bilewicz, M., Doron, G., Garoarsdóttir, R. B., Gouveia, V. V., Guan, Y., Johansson, L.-O., Pasquali, C., CorralVerdugo, V., Aragones, J. I., Utsugi, A., Demarque, C., Otto, S., Park, J., Soland, M., Steg, L., González, R., ... Saviolidis, N. M. (2016). Co-benefits of addressing climate change can motivate action around the world. Nature Climate Change, 6(2), 154157. https:/ / doi.org/10.1038/nclimate2814

Bamberg, S., \& Möser, G. (2007). Twenty years after Hines, Hungerford, and Tomera: A new metaanalysis of psycho-social determinants of proenvironmental behaviour. Journal of Environmental Psychology, 27(1), 14-25. https://doi.org/10.1016/ j.jenvp.2006.12.002

Barbett, L., Stupple, E. J. N., Sweet, M., Schofield, M. B., \& Richardson, M. (2020). Measuring actions for nature-development and validation of a pro-nature conservation behaviour scale. Sustainability, 12(12), 1-20. https:/ / doi.org/10.3390/SU12124885

Brettle, A. (2009). Systematic reviews and evidencebased library and information practice. Evidence Based Library and Information Practice, 4(1), 43. https://doi.org/10.18438/b8n613

Blok, V., Wesselink, R., Studynka, O., \& Kemp, R. (2015). Encouraging sustainability in the workplace: A survey on the pro-environmental behaviour of university employees. Journal of Cleaner Production, 106, 55-67. https://doi.org/10.1016/j.jclepro.2014. 07.063

Bogner, F. X., \& Wiseman, M. (2006). Adolescents' attitudes towards nature and environment: Quantifying the 2-MEV model. Environmentalist, 26(4), 247-254. https://doi.org/10.1007/s10669006-8660-9

Bohlen, G., Schlegelmilch, B. B., \& Diamantopoulos, A. (1993). Measuring ecological concern: A multiconstruct perspective. Journal of Marketing Management, 9(4), 415-430. https://doi.org/ 10.1080/0267257X.1993.9964250

Brende, H., Nordfjærn, T., Halvard, S., \& Rundmo, T. (2015). The value-belief-norm theory, personal norms and sustainable travel mode choice in urban areas. Journal of Environmental Psychology, 44, 119. 125. https:/ / doi.org/10.1016/j.jenvp.2015.06.001

Bronfman, N. C., Cisternas, P. C., López-vázquez, E., Maza, C. De, \& Oyanedel, J. C. (2015). Understanding attitudes and pro-environmental behaviors in a Chilean community. Sustainability, 7, 14133-14152. https:// doi.org/10.3390/su71014133 
Bruni, C. M., Chance, R. C., \& Schultz, P. W. (2012). Measuring values-based environmental concerns in children: An environmental motives scale. The Journal of Environmental Education, 43(1), 1-15. https: / / doi.org/10.1080/00958964.2011.583945

Chen, M. (2015). An examination of the value-beliefnorm theory model in predicting proenvironmental behaviour in Taiwan. Asian Journal of Social Psychology, 18, 145-151. https://doi.org/ 10.1111/ajsp.12096

Chidumayo, E. N., \& Gumbo, D. J. (2012). The environmental impacts of charcoal production in tropical ecosystems of the world: A synthesis. Energy for Sustainable Development, 17(2), 86-94. https:/ / doi.org/10.1016/j.esd.2012.07.004

Clayton, S. (2003). Environmental identity: A conceptual and an operational definition. In S. Clayton \& S. Opotow (Eds.), Identity and the natural environment: The psychological significance of nature (pp. 45-65). MIT Press.

Clayton, S. (2019). Psychology and climate change. Current Biology, 29(19), R992-R995. https:/ / doi.org/10.1016/j.cub.2019.07.017

Corral-verdugo, V., \& Armendáriz, L. I. (2000). The “new environmental paradigm" in a Mexican community. The Journal of Environmental Education, 31(3), 25-31. https:/ / doi.org/10.1080/00958960009 598642

Cruz, S. M., \& Manata, B. (2020). Measurement of environmental concern: A review and analysis. Frontiers in Psychology, 11(363), 1-14. https://doi.org/10.3389/fpsyg.2020.00363

Desrochers, J. E., Albert, G., Milfont, T. L., Kelly, B., \& Arnocky, S. (2019). Does personality mediate the relationship between sex and environmentalism? Personality and Individual Differences, 147, 204-213. https:/ / doi.org/10.1016/j.paid.2019.04.026

Duggan, J. J., Flinn, D. A., Gilbertson, K., Andre, S., \& Gaffey, T. (2004). Minnesota report card on environmental literacy. A survey of adult environmental knowledge, attitudes and behavior. https:/ / www.pca. state.mn.us/sites/default/files/p-ee5-05.pdf

Dunlap, R. E., Van Liere, K. D., Mertig, A. G., \& Jones, R. E. (2000). Measuring endorsement of the new ecological paradigm: A revised NEP scale. Journal of Social Issues, 56(3), 425-442. https://doi.org/ $10.1080 / 00958960009598667$

FAO. (2006). The state of food and agriculture: Food aid for food security? http://www.fao.org/3/a0800e/ a0800e.pdf

FAO. (2020). The state of the world's forests: Forests, biodiversity and people. https://doi.org/10.4060/ ca8642en

Félonneau, M. L., \& Becker, M. (2008). Proenvironmental attitudes and behavior: Revealing perceived social desirability. Revue Internationale de Psychologie Sociale, 21(4), 25-53.

Ghazali, E. M., Nguyen, B., \& Mutum, D. S. (2019). Proenvironmental behaviours and value-belief-norm theory: Assessing unobserved heterogeneity of two ethnic groups. Sustainability, 11(3237), 1-28. https://doi.org/10.3390/su11123237

Gibson, C. B. (1994). An investigation of gender differences in pro- environmental attitudes and behaviors. Journal of International Business Studies, 26, 255-279. https://doi.org/10.1016/S0887-6185 (98)00010-3

Gifford, R. (2011). The dragons of inaction: Psychological barriers that limit climate change mitigation and adaptation. American Psychologist, 66(4), 290-302. https://doi.org/10.1037/a0023566

Gifford, R. D., \& Chen, A. K. S. (2017). Why aren't we taking action? Psychological barriers to climatepositive food choices. Climatic Change, 140(2), 165178. https:/ / doi.org/10.1007/s10584-016-1830-y

Gifford, R., \& Nilsson, A. (2014). Personal and social factors that influence pro-environmental concern and behaviour: A review. International Journal of Psychology, 49(3), 141-157. https://doi.org/10.1002 /ijop.12034

Gifford, R., \& Sussman, R. (2012). Environmental attitudes. In S. D. Clayton (Ed.), The Oxford handbook of environmental and conservation psychology (pp. 133). https:/ / doi.org/10.1093/oxfordhb/978019973 3026.013.0004

Goulgouti, A., Plakitsi, A., \& Stylos, G. (2019). Environmental Literacy: Evaluating Knowledge, Affect, and Behavior of Pre-service Teachers in Greece. Interdisciplinary Journal of Environmental and Science Education, 15(1), 1-9. https://doi.org/ 10.29333 /ijese / 6287

Grant, M. J., \& Booth, A. (2009). A typology of reviews: An analysis of 14 review types and associated methodologies. Health Information and Libraries Journal, 26(2), 91-108. https://doi.org/10.1111/ j.1471-1842.2009.00848.x

Green, R., Milner, J., Dangour, A. D., Haines, A., Chalabi, Z., Markandya, A., Spadaro, \& Wilkinson, P. (2015). The potential to reduce greenhouse gas emissions in the UK through healthy and realistic dietary change. Climatic Change, 129(1-2), 253-265. https://doi.org/10.1007/s10584-015-1329-y

Hines, J. M., Hungerford, H. R., \& Tomera, A. N. (1987). Analysis and synthesis of research on responsible environmental behavior: A meta-analysis. The Journal of Environmental Education, 18(2), 1-8. https:/ / doi.org/10.1080/00958964.1987.9943482

Homburg, A., Stolberg, A., \& Wagner, U. (2007). Coping with global environmental problems: Development and first validation of scales. Environment and 
Behavior, 39(6), 754-778. https://doi.org/10.1177/ 0013916506297215

Hosonuma, N., Herold, M., De Sy, V., De Fries, R. S., Brockhaus, M., Verchot, L., Angelsen, A., \& Romijn, E. (2012). An assessment of deforestation and forest degradation drivers in developing countries. Environmental Research Letters, 7(4), 1-12. https:// doi.org/10.1088/1748-9326/7/4/044009

Ivanova, D., Vita, G., Steen-Olsen, K., Stadler, K., Melo, P. C., Wood, R., \& Hertwich, E. G. (2017). Mapping the carbon footprint of EU regions. Environmental Research Letters, 12(5), 1-13. https://doi.org/ 10.1088/1748-9326/aa6da9

Kaiser, F. G. (1998). A general measure of ecological behavior. Journal of Applied Social Psychology, 28(5), 395-422. https:// doi.org/10.1111/j.1559-1816.1998. tb01712.x

Kaiser, F. G., Hartig, T., Brügger, A., \& Duvier, C. (2011). Environmental protection and nature as distinct attitudinal objects: An application of the Campbell paradigm. Environment and Behavior, 45(3), 369-398. https://doi.org/10.1177/0013916511422444

Kaiser, F. G., Merten, M., \& Wetzel, E. (2018). How do we know we are measuring environmental attitude? Specific objectivity as the formal validation criterion for measures of latent attributes. Journal of Environmental Psychology, 55, 139-146. https:// doi.org/10.1016/j.jenvp.2018.01.003

Kaiser, F. G., Oerke, B., \& Bogner, F. X. (2007). Behaviorbased environmental attitude: Development of an instrument for adolescents. Journal of Environmental Psychology, 27(3), 242-251. https:/ / doi.org/10.1016 /j.jenvp.2007.06.004

Kaiser, F. G., Wolfing, S., \& Fuhrer, U. (1999). Environmental attitudes and ecological behaviour. Journal of Environmental Psychology, 19, 1-19. https:// doi.org/10.1006/jevp.1998.0107

Karpudewan, M., Ismail, Z., \& Roth, W. M. (2012). Promoting pro-environmental attitudes and reported behaviors of Malaysian pre-service teachers using green chemistry experiments. Environmental Education Research, 18(3), 375-389. https:/ / doi.org/10.1080/13504622.2011.622841

Khan, K. S., Kunz, R., Kleijnen, J., \& Antes, G. (2003). Five steps to conducting a systematic review. Journal of the Royal Society of Medicine, 96(3), 118-121. https:// doi.org/10.1258/jrsm.96.3.118

Krieger, M. A., Chung-Yan, G. A., \& Towson, S. M. J. (2017). Social psycological theory. In J. A. Gruman, F. W. Schneider, \& L. M. Coutts (Eds.), Foundations of applied social psychology (Third, pp. 27-44). https:// doi.org/10.4135/9781071800591.n2

Kuhn, R. G., \& Jackson, E. L. (1989). Stability of factor structures in the measurement of public environmental attitudes. The Journal of
Environmental Education, 20(3), 27-32. https:/ / doi.org/10.1080/00958964.1989.9942786

Kurisu, K. (2015). Pro-environmental behaviors. In ProEnvironmental Behaviors (pp. 1-26). https:/ / doi.org/ 10.1007/978-4-431-55834-7

Lange, F., \& Dewitte, S. (2019). Measuring proenvironmental behavior: Review and recommendations. Journal of Environmental Psychology, 63, 92-100. https://doi.org/10.1016/ j.jenvp.2019.04.009

Leeming, F. C., Dwyer, W. O., \& Bracken, B. A. (1995). Children's environmental attitude and knowledge scale: Construction and validation, The Journal of Environmental Education, 26(3), 22-31. https:// doi.org/10.1080/00958964.1995.9941442

Lizundia-Loiola, J., Pettinari, M. L., \& Chuvieco, E. (2020). Temporal anomalies in burned area trends: Satellite estimations of the Amazonian 2019 fire crisis. Remote Sensing, 12(1), 151. https:// doi.org/10.3390/rs12010151

Maloney, M. P., Ward, M. P., \& Braucht, G. N. (1975). Psychology in action: A revised scale for the measurement of ecological attitudes and knowledge of. American Psychologist, 30, 787-790. https:// doi.org/10.1037/h0084394

Maurer, M., \& Bogner, F. X. (2019). How freshmen perceive Environmental Education (EE) and Education for Sustainable Development (ESD). PLoS ONE, 14(1), 1-16. https://doi.org/10.1371/ journal.pone.0208910

McIntyre, A., \& Milfont, T. L. (2016). Who cares? Measuring environmental attitudes. In Research Methods for Environmental Psychology (pp. 93-114). https://doi.org/10.1002/9781119162124.ch6

Mensah, J. (2019). Sustainable development: Meaning, history, principles, pillars, and implications for human action: Literature review. Cogent Social Sciences, 5(1), 1-21. https://doi.org/10.1080/ 23311886.2019.1653531

Milfont, T. L. (2007). Psychology of Environmental Attitudes A cross-cultural study of their content and structure (Auckland). https://researchspace.auckland.ac.nz / bitstream/handle/2292/1712/02whole.pdf?sequ ence $=5 \&$ is Allowed $=y$

Milfont, T. L. (2012). The psychology of environmental attitudes: Conceptual and emperical insights from New Zealand. Ecopsychology, 4(4), 269-276. https:/ / doi.org/10.1089/eco.2012.0058

Milfont, T. L., \& Duckitt, J. (2006). Preservation and utilization: Understanding the structure of environemental attitudes. Medio Ambiente y Comportamiento Humano, 7(1), 29-50.

Milfont, T. L., \& Duckitt, J. (2010). The environmental attitudes inventory: A valid and reliable measure to 
assess the structure of environmental attitudes. Journal of Environmental Psychology, 30(1), 80-94. https://doi.org/10.1016/j.jenvp.2009.09.001

Milfont, T. L., Bain, P. G., Kashima, Y., Corral-Verdugo, V., Pasquali, C., Johansson, L. O., ... Einarsdóttir, G. (2017). On the relation between social dominance orientation and environmentalism: A 25-Nation Study. Social Psychological and Personality Science, 9(7), 802-814. https:/ / doi.org/10.1177/1948550617 722832

Milfont, T. L., Osborne, D., Yogeeswaran, K., \& Sibley, C. G. (2020). The role of national identity in collective pro-environmental action. Journal of Environmental Psychology, 72, 101522. https://doi.org/10.1016/ j.jenvp.2020.101522

Milfont, T. T., Duckitt, J., \& Cameron, L. D. (2006). A cross-cultural study of environmental motive concerns and their implications for proenvironmental behavior. Environment and Behavior, 38(6), 745-767. https://doi.org/10.1177/ 0013916505285933

Mkonda, M., \& He, X. (2017). The emerging population increase and its environmental challenges and remedies in Iringa municipal, Tanzania. Journal of Geography, Environment and Earth Science International, 9(2), 1-11. https://doi.org/10.9734/ jgeesi/2017/31072

Nielsen, K. S., Clayton, S., Stern, P. C., Dietz, T., Capstick, S., \& Whitmarsh, L. (2020). How Psychology Can Help Limit Climate Change. American Psychologist. https:/ / doi.org/10.1037/amp0000624

Ogunbode, C. A., Henn, L., \& Tausch, N. (2018). Contextappropriate environmental attitude measurement in Nigeria using the Campbell paradigm. Environment, Development and Sustainability, 22(3), 2141-2158. https://doi.org/10.1007/s10668-0180281-1

Olsson, D., Gericke, N., Sass, W., \& Boeve-de Pauw, J. (2020). Self-perceived action competence for sustainability: the theoretical grounding and empirical validation of a novel research instrument. Environmental Education Research, 26(5), 742-760. https:/ / doi.org/10.1080/13504622.2020.1736991

Ones, D. S., \& Dilchert, S. (2012). Environmental sustainability at work: A call to action. Industrial and Organizational Psychology, 5(4), 444-466. https://doi.org/10.1111/j.1754-9434.2012.01478.x

Otto, S., Evans, G. W., Moon, M. J., \& Kaiser, F. G. (2019). The development of children's environmental attitude and behavior. Global Environmental Change, 58(1), 1-6. https://doi.org/10.1016/j.gloenvcha. 2019.101947

Palupi, T., \& Sawitri, D. R. (2018). The importance of proenvironmental behavior in adolescents. E3S Web of
Conferences, 31, 2-5. https://doi.org/10.1051/ e3sconf/20183109031

Pelletier, L., Legault, L., \& Tuson, K. M. (1996). The environmental satisfaction scale. Environment and Behavior, 28(1), 5-26. https://doi.org/10.1177/ 0013916596281001

Petegem, P. V., \& Blieck, A. (2006). The environmental worldview of children: a cross-cultural perspective. Environmental Education Research, 12(5), 625-635. https:// doi.org/10.1080/13504620601053662

Polasky, S., Kling, C. L., Levin, S. A., Carpenter, S. R., Daily, G. C., Ehrlich, P. R., Heal, G. M., \& Lubchenco, J. (2019). Role of economics in analyzing the environment and sustainable development. Proceedings of the National Academy of Sciences of the United States of America, 116(12), 52335238. https:// doi.org/10.1073/pnas.1901616116

Poore, J., \& Nemecek, T. (2018). Reducing food's environmental impacts through producers and consumers. Science, 360(6392), 987-992. https:// doi.org/10.1126/science.aaq0216

Proctor, R. W., \& Vu, K. P. L. (2019). How psychologists help solve real-world problems in multidisciplinary research teams: Introduction to the special issue. American Psychologist, 74(3), 271277. https:// doi.org/10.1037/amp0000458

Rajapaksa, D., Gifford, R., Torgler, B., Garcia-Valiñas, M., Athukorala, W., Managi, S., \& Wilson, C. (2019). Do monetary and non-monetary incentives influence environmental attitudes and behavior? Evidence from an experimental analysis. Resources, Conservation and Recycling, 149, 168-176. https:/ / doi.org/10.1016/j.resconrec.2019.05.034

Richardson, M., Hunt, A., Hinds, J., Bragg, R., Fido, D., Petronzi, D., Barbett, L., Clitherow, T., \& White, M. (2019). A measure of nature connectedness for children and adults: Validation, performance, and insights. Sustainability, 11(12), 1-16. https:/ / doi.org /10.3390/SU11123250

Ripple, W. J., Wolf, C., Newsome, T. M., Galetti, M., Alamgir, M., Crist, E., Mahmoud, M. I., \& Laurance, W. F. (2017). World Scientists' Warning to Humanity: A Second Notice. BioScience, 67(12), 1026-1028. https://doi.org/10.1093/biosci/bix125

Roberts, J. A. (1995). Profiling levels of socially responsible consumer behavior: A cluster analytic approach and its implications for marketing. Journal of Marketing Theory and Practice, 3(4), 97-117. https:/ / doi.org/10.1080/10696679.1995.11501709

Rokeach, M. (1967). Attitude change and behavioral change. Public Opinion Quarterly, 30(4), 529-550. https://www.jstor.org/stable/pdf/2746961.pdf

Rossano, V., Roselli, T., \& Calvano, G. (2017). A serious game to promote environmental attitude. Smart 
Innovation, Systems and Technologies, 75, 48-55. https:/ / doi.org/10.1007/978-3-319-59451-4_5

Ruepert, A., Keizer, K., Steg, L., Maricchiolo, F., Carrus, G., Dumitru, A., Mira, R. G., Stancu, A., \& Moza, D. (2016). Environmental considerations in the organizational context: A pathway to proenvironmental behaviour at work. Energy Research and Social Science, 17, 59-70. https:/ / doi.org/10.1016/j.erss.2016.04.004

Samputri, S., \& Safitri, D. (2020). Environmental knowledge, ecosystem and attitude toward environmentally friendly behavior for coastal community. Aquademia, 4(2), ep20027. https:/ / doi.org/10.29333/aquademia/8580

Sawitri, D. R., Hadiyanto, H., \& Hadi, S. P. (2015). Proenvironmental behavior from a socialcognitive theory perspective. Procedia Environmental Sciences, 23, 27-33. https://doi.org/10.1016/j.proenv.2015. 01.005

Schmidt, F. N., \& Gifford, R. (1989). A dispositional approach to hazard perception: Preliminary development of the environmental appraisal inventory. Journal of Environmental Psychology, 9(1), 57-67. https://doi.org/10.1016/S0272-4944(89) 80026-X

Schmuck, P., \& Schultz, W. P. (2003). Psychology of sustainable development. In P. Schmuck \& W. P. Schultz (Eds.), Psychology of sustainable development (pp. 3-17). Springer Science+Business Media.

Schultz, P. W. (2000). Empathizing with nature: The effects of perspective taking on concern for environmental education. Journal of Social Issues, 56(3), 391-406. Journal of Social Issues, 56(3), 391-406. https://doi.org/10.1111/0022-4537.00174

Schultz, P. Wesley. (2001). The structure of environmental concern: Concern for self, other people, and the biosphere. Journal of Environmental Psychology, 21(4), 327-339. https:/ / doi.org/10.1006/jevp.2001.0227

Schwartz, S. H. (1977). Normative influences on altruism. Advances in Experimental Social Psychology, 10(C), 221-279. https://doi.org/10.1016/S00652601(08)60358-5

Sedano, F., Silva, J. A., Machoco, R., Meque, C. H., Sitoe, A., Ribeiro, N., Anderson, K., Ombe, Z. A., Baule, S. H., \& Tucker, C. J. (2016). The impact of charcoal production on forest degradation: A case study in Tete, Mozambique. Environmental Research Letters, 11(9), 1-12. https://doi.org/10.1088/17489326/11/9/094020

Shi, L., Han, L., Yang, F., \& Gao, L. (2019). The evolution of sustainable development theory: Types, goals, and research prospects. Sustainability, 11(24), 1-16. https://doi.org/10.3390/su11247158
Shulla, K., Filho, W. L., Lardjane, S., Sommer, J. H., \& Borgemeister, C. (2020). Sustainable development education in the context of the 2030 Agenda for sustainable development. International Journal of Sustainable Development and World Ecology, 00(00), 111. https:/ / doi.org/10.1080/13504509.2020.1721378

Steg, L., \& Vlek, C. (2009). Encouraging proenvironmental behaviour: An integrative review and research agenda. Journal of Environmental Psychology, 29(3), 309-317. https://doi.org/10.1016 /j.jenvp.2008.10.004

Stehfest, E., Bouwman, L., Van Vuuren, D. P., Den Elzen, M. G. J., Eickhout, B., \& Kabat, P. (2009). Climate benefits of changing diet. Climatic Change, 95(1-2), 83-102. https://doi.org/10.1007/s10584-008-95346

Stern, P. C. (2000). Toward a coherent theory of environmentally significant behavior. Journal of Social Issues, 56(3), 407-424. https://doi.org/ 10.1111/0022-4537.00175

Stern, P. C., Dietz, T., Abel, T., Guagnano, G. A., \& Kalof, L. (1999). A value-belief-norm theory of support for social movements: The case of environmentalism. Research in Human Ecology, 6(2), 81-97.

Stern, P. C., Dietz, T., \& Guagnano, G. A. (1998). A brief inventory of values. Educational and Psychological Measurement, 58(6), 984-1001. https://doi.org/ $10.1177 / 0013164498058006008$

Sudbury-Riley, L., \& Kohlbacher, F. (2015). Ethically minded consumer behavior: Scale review, development, and validation. Journal of Business Research, 69(8), 2697-2710. https:/ / doi.org/10.1016 /j.jbusres.2015.11.005

Taufique, K. M. R., Siwar, C., Chamhuri, N., \& Sarah, F. H. (2016). Integrating general environmental knowledge and eco-label knowledge in understanding ecologically conscious consumer behavior. Procedia Economics and Finance, 37(16), 3945. https://doi.org/10.1016/s2212-5671(16)300909

Tonglet, M., Phillips, P. S., \& Read, A. D. (2004). Using the theory of planned behaviour to investigate the determinants of recycling behaviour: A case study from Brixworth, UK. Resources, Conservation and Recycling, 41(3), 191-214. https:/ / doi.org/10.1016/ j.resconrec.2003.11.001

Trobe, H. L. La, \& Acott, T. G. (2000). A modified NEP / DSP environmental attitudes scale. The Journal of Environmental Education, 32(1), 12-20.

UN. (1992). UN Conference on Environment and Development (Vol. 6). https://doi.org/10.4135/ 9781412971867.n128

UN. (2015). Arsenic and the 2030 Agenda for sustainable development. In Transforming our world: The 2030 
agenda for sustainable development. https:/ / doi.org/10.1201/b20466-7

Van Lange, P. A. M., Joireman, J., \& Milinski, M. (2018). Climate change: What psychology can offer in terms of insights and solutions. Current Directions in Psychological Science, 27(4), 269-274. https:/ / doi.org/10.1177/0963721417753945

Venter, O., Sanderson, E. W., Magrach, A., Allan, J. R., Beher, J., Jones, K. R., Possingham, H. P., Laurance, W. F., Wood, P., Fekete, B. M., Levy, M. A., \& Watson, J. E. M. (2016). Sixteen years of change in the global terrestrial human footprint and implications for biodiversity conservation. Nature Communications, 7, 1-11. https://doi.org/10.1038/ ncomms12558

Voulvoulis, N., \& Burgman, M. A. (2019). The contrasting roles of science and technology in environmental challenges. Critical Reviews in Environmental Science and Technology, 49(12), 10791106.

https:/ / doi.org/10.1080/10643389.2019.1565519

Wallen, K., \& Landon, A. (2020). Systematic map of conservation social psychology research. Conservation Biology, 34(6), 1339-1352. https: / / doi.org/10.31235/osf.io/bjtfn

Weigel, R., \& Weigel, J. (1978). Environmental concern: The development of a measure. Environment and Behavior, 10(1), 1-15. https://doi.org/10.1177/ 0013916578101001

Whitburn, J., Linklater, W., \& Abrahamse, W. (2020). Meta-analysis of human connection to nature and proenvironmental behavior. Conservation Biology, 34(1), 180-193. https:// doi.org/10.1111/cobi.13381

Williams, D. R., Balmford, A., \& Wilcove, D. S. (2020). The past and future role of conservation science in saving biodiversity. Conservation Letters, 13(4), 1-7. https://doi.org/10.1111/conl.12720

Wiseman, M., \& Bogner, F. X. (2003). A higher-order model of ecological values and its relationship to personality. Personality and Individual Differences, 34(5), 783-794. https://doi.org/10.1016/S01918869(02)00071-5

World Commission on Environment and Development (WCED). (1987). Our common future. Oxford: Oxford University Press. https://doi.org/ 10.1177/0013916509335163

Yu, P., Xu, R., Abramson, M. J., Li, S., \& Guo, Y. (2020). Bushfires in Australia: a serious health emergency under climate change. The Lancet Planetary Health, 4(1), e7-e8. https://doi.org/10.1016/S2542-5196 (19)30267-0

Zachariou, F., Voulgari, I., Tsami, E., \& Bersimis, S. (2020). Exploring the Attitudes of Secondary Education Students on Environmental Education in Relation to their Perceptions on Environmental Problems: The Case of the Prefecture of Viotia. Interdisciplinary Journal of Environmental and Science Education, 16(1), 1-13. https://doi.org/10.29333/ ijese/ 6442

Zmami, M., \& Ben-Salha, O. (2020). An empirical analysis of the determinants of $\mathrm{CO} 2$ emissions in GCC countries. International Journal of Sustainable Development and World Ecology, 27(5), 1-12. https://doi.org/10.1080/13504509.2020.1715508

Zulu, L. C., \& Richardson, R. B. (2013). Charcoal, livelihoods, and poverty reduction: Evidence from sub-Saharan Africa. Energy for Sustainable Development, 17(2), 127-137. https://doi.org/ 10.1016/j.esd.2012.07.007 
APPENDIX

\section{A Summary of the Reviewed Scales}

\begin{tabular}{|c|c|c|c|c|c|c|c|c|c|c|c|c|c|}
\hline Author (s) & Scale name & Reg & Level & Items & Climate & Littering & Forestry & Biodiversity & Pollution & Technology & Scarce $r$ & General & Any other \\
\hline Roberts (1995) & $\begin{array}{l}\text { Socially } \\
\text { Responsible } \\
\text { Consumer } \\
\text { Behavior (SRCB) } \\
\text { Scale }\end{array}$ & N. A & Adults & 25 & 0 & 7 & 0 & 0 & 4 & 0 & 2 & 12 & $\begin{array}{c}\text {-Minority groups } \\
\text {-Gender, regional } \\
\text { differences (S.A) } \\
\text {-Green } \\
\text { consumerism } \\
\text {-Eco-information } \\
\text {-Boycotting } \\
\text {-Donating for } \\
\text { nature }\end{array}$ \\
\hline $\begin{array}{l}\text { Maloney, } \\
\text { Ward, \& } \\
\text { Braucht (1975) }\end{array}$ & $\begin{array}{l}\text { A Revised Scale } \\
\text { for the } \\
\text { Measurement of } \\
\text { Ecological } \\
\text { Attitudes and } \\
\text { Knowledge } \\
\text { (MEAK-R) }\end{array}$ & N. A & Adults & 45 & 0 & 1 & 0 & 0 & 30 & 0 & 0 & 14 & $\begin{array}{c}\text { - Donating for } \\
\text { nature } \\
\text {-Eco-information } \\
\text {-Green } \\
\text { consumerism } \\
\text {-Increase in tax } \\
\text {-Industrial } \\
\text { activities }\end{array}$ \\
\hline $\begin{array}{l}\text { Leeming et al. } \\
\text { (1995) }\end{array}$ & $\begin{array}{l}\text { Children's } \\
\text { Environmental } \\
\text { Attitude and } \\
\text { Knowledge Scale } \\
\text { (CHEAKS)* }^{*}\end{array}$ & N. A & Children & 66 & 0 & 11 & 0 & 12 & 15 & 0 & 16 & 12 & $\begin{array}{c}\text {-Donating for } \\
\text { nature } \\
\text {-Eco-information } \\
\text {-Green } \\
\text { consumerism }\end{array}$ \\
\hline $\begin{array}{l}\text { Thompson \& } \\
\text { Barton (1994) }\end{array}$ & $\begin{array}{l}\text { Ecocentric and } \\
\text { Anthropocentric } \\
\text { Attitudes Toward } \\
\text { the Environment }\end{array}$ & N. A & Adults & 33 & 1 & 1 & 6 & 10 & 2 & 1 & 3 & 9 & $\begin{array}{l}\text {-Population } \\
\text { growth } \\
\text {-Enjoyment of } \\
\text { nature }\end{array}$ \\
\hline $\begin{array}{l}\text { Dunlap et al. } \\
(2000)\end{array}$ & $\begin{array}{l}\text { New Ecological } \\
\text { Paradigm Scale } \\
\text { (NEP-R) }\end{array}$ & N. A & Adults & 15 & 0 & 0 & 0 & 1 & 0 & 0 & 2 & 12 & $\begin{array}{l}\text {-Population } \\
\text { growth } \\
\text {-Human } \\
\text { dominance }\end{array}$ \\
\hline Kaiser (1998) & $\begin{array}{l}\text { The General } \\
\text { Ecological } \\
\text { Behavior (GEB) } \\
\text { Scale }\end{array}$ & Europe & Adults & 38 & 0 & 10 & 0 & 1 & 12 & 0 & 5 & 10 & $\begin{array}{l}\text {-Eco-information } \\
\text { - Donating for } \\
\text { nature } \\
\text {-Dishonest } \\
\text {-Enjoyment of } \\
\text { nature } \\
\text {-Social altruistic }\end{array}$ \\
\hline $\begin{array}{l}\text { Kaiser et al. } \\
(2007)\end{array}$ & $\begin{array}{l}\text { Behavior-Based } \\
\text { Environmental } \\
\text { Attitude Scale }\end{array}$ & Europe & Adolesc. & 40 & 0 & 16 & 0 & 0 & 6 & 0 & 7 & 11 & $\begin{array}{c}\text {-Donating for } \\
\text { nature } \\
\text {-Eco-information } \\
\text {-Green } \\
\text { consumerism }\end{array}$ \\
\hline $\begin{array}{l}\text { Kaiser \& } \\
\text { Wilson (2004) }\end{array}$ & $\begin{array}{l}\text { The General } \\
\text { Ecological } \\
\text { Behavior (GEB) } \\
\text { Scale }\end{array}$ & Europe & Adults & 50 & 0 & 12 & 1 & 0 & 15 & 0 & 13 & 9 & $\begin{array}{c}\text {-Green } \\
\text { consumerism } \\
\text {-Eco-information } \\
\text { - Donating for } \\
\text { nature } \\
\text {-Activism }\end{array}$ \\
\hline $\begin{array}{l}\text { Kaiser et al. } \\
\text { (1999) }\end{array}$ & $\begin{array}{l}\text { Environmental } \\
\text { Attitude and } \\
\text { Ecological } \\
\text { Behavior Scale }\end{array}$ & Europe & Adults & 28 & 15 & 0 & 0 & 7 & 2 & 0 & 0 & 4 & $\begin{array}{l}\text {-Donating for } \\
\text { nature }\end{array}$ \\
\hline $\begin{array}{l}\text { Sudbury-Riley } \\
\& \text { Kohlbacher } \\
(2015)\end{array}$ & $\begin{array}{l}\text { Ethically Minded } \\
\text { Consumer } \\
\text { Behavior (EMCB) } \\
\text { Scale }\end{array}$ & $\begin{array}{c}\text { Europe, } \\
\text { Asia }\end{array}$ & Adults & 10 & 0 & 2 & 0 & 0 & 0 & 0 & 0 & 8 & $\begin{array}{c}\text {-Minority groups } \\
\text {-Green } \\
\text { consumerism } \\
\text {-Boycotting } \\
\text { - Donating for } \\
\text { nature }\end{array}$ \\
\hline $\begin{array}{l}\text { Trobe \& Acott } \\
(2000)\end{array}$ & $\begin{array}{l}\text { A Modified } \\
\text { NEP/DSP } \\
\text { Environmental } \\
\text { Attitudes Scale }\end{array}$ & Europe & Adults & 21 & 0 & 0 & 1 & 4 & 0 & 1 & 1 & 14 & $\begin{array}{c}\text {-Industrial } \\
\text { activities } \\
- \\
\text { Anthropocentris } \\
\text { m } \\
\text {-Economic } \\
\text { growth }\end{array}$ \\
\hline $\begin{array}{l}\text { Bogner \& } \\
\text { Wiseman } \\
(2006)\end{array}$ & The 2-MEV Scale & Europe & $\begin{array}{l}\text { Children } \\
(9-12)\end{array}$ & 20 & 0 & 0 & 1 & 5 & 2 & 0 & 3 & 9 & $\begin{array}{c}\text {-Enjoyment of } \\
\text { nature } \\
- \\
\text { Anthropocentris } \\
\mathrm{m} \\
\text {-Enjoyment of } \\
\text { nature }\end{array}$ \\
\hline
\end{tabular}


\begin{tabular}{llllll}
\hline Author (s) & Scale name & Reg & Level & Items & Climate Littering Forestry Biodiversity Pollution Technology Scarce $\mathrm{r}$ General Any other
\end{tabular}

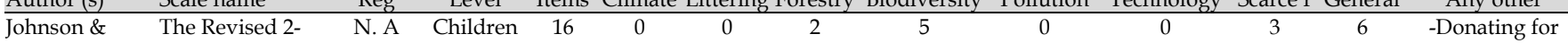

Anthropocentris

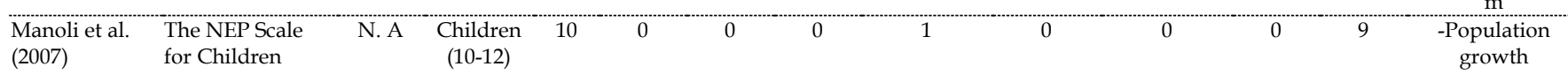

Anthropocentris

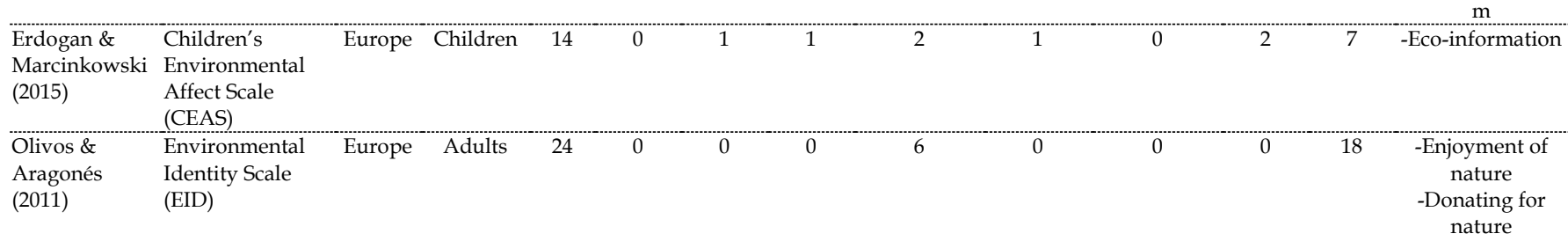

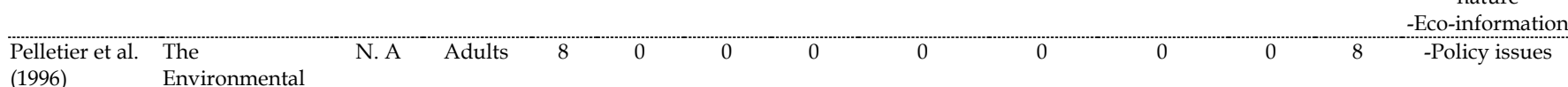

(1996) Environmental

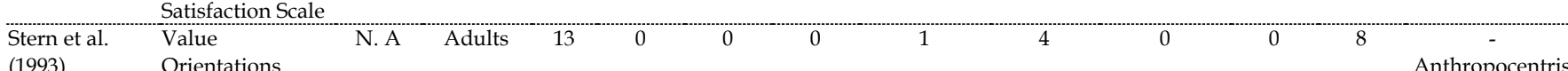

(1993) Orientations Anthropocentris Scale

-Boycotting

- Donating for nature

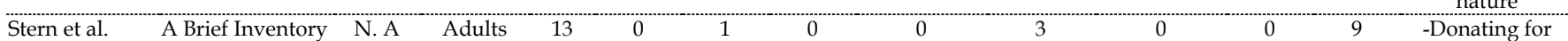

(1998) of Values nature

-Green

consumerism

-Activism

-Eco-information

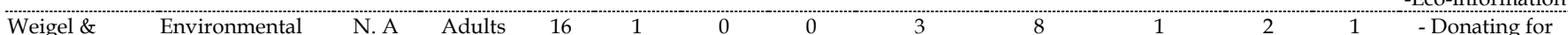

Weigel (1978) Concern Scale nature

$\begin{array}{llllllllll}\text { Milfont \& } & \text { Environmental } & \text { Oceania } & \text { Adults } & 120 & 0 & 7 & 8 & 21 & 5\end{array}$

$\begin{array}{llccccccc}\text { Milfont \& } & \text { Environmental } & \text { Oceania } & \text { Adults } & 120 & 0 & 21 & 5 & 8 \\ & \text { Attitudes } & \text { Africa } & & & & \text { nature } \\ & \text { Inventory (EAI) } & \text { S. A } & & & \text {-Donating for }\end{array}$

nature

-Eco-information

Anthropocentris

$\mathrm{m}$

-Population

growth

\begin{tabular}{|c|c|c|c|c|c|c|c|c|c|c|c|c|c|}
\hline $\begin{array}{l}\text { Musser \& } \\
\text { Malkus (1994) }\end{array}$ & $\begin{array}{l}\text { The Children's } \\
\text { Attitudes Toward } \\
\text { the Environment } \\
\text { Scale (CATES) }\end{array}$ & Asia & Children & 25 & 0 & 6 & 1 & 9 & 3 & 0 & 4 & 2 & $\begin{array}{c}\text { Anthropocentris } \\
\mathrm{m}\end{array}$ \\
\hline $\begin{array}{l}\text { Musser \& } \\
\text { Diamond } \\
(2010)\end{array}$ & $\begin{array}{l}\text { The Children's } \\
\text { Attitudes Toward } \\
\text { the Environment } \\
\text { Scale for } \\
\text { Preschool } \\
\text { Children } \\
\text { (CATES-PV) }\end{array}$ & Asia & Children & 15 & 1 & 5 & 0 & 6 & 0 & 0 & 2 & 1 & $\begin{array}{c}\text {-Enjoyment of } \\
\text { nature }\end{array}$ \\
\hline Markle (2013) & $\begin{array}{l}\text { Pro- } \\
\text { Environmental } \\
\text { Behavior Scale } \\
\text { (PEBS) }\end{array}$ & N. A & Adults & 18 & 3 & 0 & 0 & 2 & 3 & 0 & 7 & 3 & $\begin{array}{c}\text {-Eco-information } \\
\text {-Donating for } \\
\text { nature } \\
\text {-Green } \\
\text { consumerism }\end{array}$ \\
\hline $\begin{array}{l}\text { Kaiser et al. } \\
(2011)\end{array}$ & $\begin{array}{l}\text { Campbell's } \\
\text { Paradigm Scale } \\
\text { for measuring } \\
\text { attitudes }\end{array}$ & Europe & Adults & 90 & 2 & 12 & 8 & 25 & 12 & 0 & 15 & 16 & $\begin{array}{c}\text {-Eco-information } \\
\text { - Donating for } \\
\text { nature } \\
\text {-Green } \\
\text { consumerism } \\
\text {-Enjoyment of } \\
\text { nature }\end{array}$ \\
\hline $\begin{array}{l}\text { Ugulu et al. } \\
(2013)\end{array}$ & $\begin{array}{l}\text { Environmental } \\
\text { Attitude Scale } \\
\text { (EAS) }\end{array}$ & Europe & Adults & 36 & 0 & 17 & 2 & 3 & 2 & 0 & 4 & 8 & $\begin{array}{c}\text {-Eco-information } \\
- \\
\text { Anthropocentris } \\
m\end{array}$ \\
\hline $\begin{array}{l}\text { Hamza et al. } \\
(2008)\end{array}$ & $\begin{array}{l}\text { Environmental } \\
\text { Attitudes of the } \\
\text { University (EAU) } \\
\text { Scale }\end{array}$ & Europe & Adults & 20 & 0 & 1 & 0 & 3 & 2 & 2 & 0 & 12 & $\begin{array}{c}\text {-Eco-information } \\
\text {-Green } \\
\text { consumerism } \\
\text {-Policy issues } \\
\end{array}$ \\
\hline
\end{tabular}




\begin{tabular}{|c|c|c|c|c|c|c|c|c|c|c|c|c|c|}
\hline Author (s) & Scale name & Reg & Level & Items & Climate & Littering & g Forestry & Biodiversity & Pollution & Technology & Scarce $r$ & General & Any other \\
\hline $\begin{array}{l}\text { Lounsbury \& } \\
\text { Tornatzky } \\
\text { (1977) }\end{array}$ & $\begin{array}{l}\text { Attitudes Toward } \\
\text { Environmental } \\
\text { Quality Scale }\end{array}$ & N. A & Adults & 12 & 0 & 2 & 0 & 0 & 4 & 1 & 2 & 3 & $\begin{array}{l}\text {-Population } \\
\text { growth }\end{array}$ \\
\hline $\begin{array}{l}\text { Bohlen et al. } \\
\text { (1993). }\end{array}$ & $\begin{array}{l}\text { Ecological Concern } \\
\text { Scale }\end{array}$ & Europe & Adults & 15 & 0 & 5 & 0 & 2 & 1 & 0 & 2 & 5 & $\begin{array}{c}\text {-Activism } \\
\text {-Green } \\
\text { consumerism } \\
\text {-Eco-information }\end{array}$ \\
\hline $\begin{array}{l}\text { Robin et al. } \\
(2007)\end{array}$ & $\begin{array}{l}\text { The scale of } \\
\text { Perceived } \\
\text { Environmental } \\
\text { Annoyances in } \\
\text { Urban Settings } \\
\text { (SPEAUS) }\end{array}$ & Europe & Adults & 51 & 0 & 3 & 0 & 1 & 12 & 0 & 0 & 35 & $\begin{array}{c}\text {-Social altruistic } \\
\text {-Population } \\
\text { growth }\end{array}$ \\
\hline $\begin{array}{l}\text { Kuhn \& } \\
\text { Jackson } \\
(1989)\end{array}$ & $\begin{array}{l}\text { Environmental } \\
\text { Attitude Scale }\end{array}$ & N. A & Adults & 21 & 0 & 0 & 0 & 0 & 0 & 5 & 2 & 14 & $\begin{array}{c}\text {-Economic } \\
\text { growth } \\
- \\
\text { Anthropocentris } \\
\text { m } \\
\text {-Population } \\
\text { growth }\end{array}$ \\
\hline $\begin{array}{l}\text { Schmidt \& } \\
\text { Gifford } \\
(1989)\end{array}$ & $\begin{array}{l}\text { Environmental } \\
\text { Appraisal } \\
\text { Inventory (EAI) }\end{array}$ & N. A & Adults & 24 & 0 & 0 & 1 & 0 & 16 & 0 & 3 & 4 & $\begin{array}{l}\text {-Population } \\
\text { growth }\end{array}$ \\
\hline $\begin{array}{l}\text { Berberoglu } \\
\& \\
\text { Tosunoglu } \\
(1995)\end{array}$ & $\begin{array}{l}\text { Environmental } \\
\text { Attitude Scale }\end{array}$ & Europe & Adults & 18 & 0 & 0 & 0 & 0 & 0 & 6 & 4 & 8 & $\begin{array}{l}\text {-Population } \\
\text { growth } \\
\text {-Enjoyment of } \\
\text { nature } \\
\text {-Increased tax }\end{array}$ \\
\hline Shultz (2000) & $\begin{array}{l}\text { Environmental } \\
\text { Motive Scale (EMS) }\end{array}$ & N. A & Adults & 12 & 0 & 0 & 0 & 4 & 0 & 0 & 0 & 8 & $\begin{array}{c}\text { Anthropocentris } \\
\mathrm{m} \\
\text {-Social altruistic }\end{array}$ \\
\hline $\begin{array}{l}\text { Bruni et al. } \\
\text { (2012) }\end{array}$ & $\begin{array}{l}\text { Children's } \\
\text { Environmental } \\
\text { Motives Scale } \\
\text { (ChEMS) }\end{array}$ & Europe & Adolesc. & 12 & 0 & 0 & 2 & 3 & 0 & 0 & 0 & 7 & $\begin{array}{c}\text { - } \\
\text { Anthropocentris } \\
\mathrm{m} \\
\text {-Social altruistic }\end{array}$ \\
\hline $\begin{array}{l}\text { Kaplan } \\
\text { (1973) }\end{array}$ & $\begin{array}{l}\text { Garden Benefit } \\
\text { Scales }\end{array}$ & N.A & Adults & 13 & 0 & 0 & 2 & 2 & 0 & 0 & 1 & 8 & $\begin{array}{l}\text {-Enjoyment of } \\
\text { nature }\end{array}$ \\
\hline $\begin{array}{l}\text { McKechnie } \\
(1977)\end{array}$ & $\begin{array}{l}\text { Environmental } \\
\text { Response Inventory } \\
\text { (ERI) }\end{array}$ & N. A & Adults & 36 & 0 & 1 & 2 & 1 & 1 & 2 & 3 & 26 & $\begin{array}{c}\text {-Population } \\
\text { growth } \\
- \\
\text { Anthropocentris } \\
\text { m }\end{array}$ \\
\hline $\begin{array}{l}\text { Blok et al. } \\
\text { (2015) }\end{array}$ & $\begin{array}{l}\text { Pro-environmental } \\
\text { Behavior Scale }\end{array}$ & Europe & Adults & 80 & 1 & 16 & 0 & 2 & 3 & 6 & 7 & 45 & $\begin{array}{c}\text {-Green } \\
\text { consumerism } \\
\text {-Eco-information } \\
\text {-Policy issues } \\
\text {-Social altruistic }\end{array}$ \\
\hline $\begin{array}{l}\text { Clayton } \\
(2003)\end{array}$ & $\begin{array}{l}\text { Environmental } \\
\text { Identity Scale }\end{array}$ & N. A & Adults & 24 & 0 & 0 & 1 & 4 & 0 & 0 & 1 & 18 & $\begin{array}{l}\text {-Enjoyment of } \\
\text { nature } \\
\text {-Donating for } \\
\text { nature }\end{array}$ \\
\hline $\begin{array}{l}\text { Homburg et } \\
\text { al. (2007) }\end{array}$ & $\begin{array}{l}\text { Coping with Global } \\
\text { Environmental } \\
\text { Problems Scales }\end{array}$ & Europe & Adults & 41 & 2 & 0 & 0 & 0 & 1 & 0 & 0 & 38 & -Eco-information \\
\hline Kim (2017) & $\begin{array}{l}\text { Pro-environmental } \\
\text { Behavior Scale for } \\
\text { Women's Health } \\
\text { (PEBS-WH) }\end{array}$ & Asia & Adults & 17 & 0 & 1 & 0 & 0 & 8 & 0 & 1 & 7 & -Eco-information \\
\hline $\begin{array}{l}\text { Barbett et al. } \\
(2020)\end{array}$ & $\begin{array}{l}\text { Pro-Nature } \\
\text { Conservation } \\
\text { Behaviour Scale } \\
\text { (ProCoBS) }\end{array}$ & Europe & Adults & 18 & 0 & 2 & 7 & 2 & 1 & 0 & 0 & 6 & $\begin{array}{c}\text {-Eco-information } \\
\text {-Policy issues } \\
\text {-Donating for } \\
\text { nature } \\
\text {-Activism }\end{array}$ \\
\hline $\begin{array}{l}\text { Schultz } \\
\text { (2002) }\end{array}$ & $\begin{array}{l}\text { The Inclusion of } \\
\text { Nature in Self (INS) } \\
\text { Scale }\end{array}$ & N.A & Adults & 1 & 0 & 0 & 0 & 0 & 0 & 0 & 0 & 1 & \\
\hline $\begin{array}{l}\text { Olsson et al. } \\
(2020)\end{array}$ & $\begin{array}{l}\text { The Self-Perceived } \\
\text { Action Competence } \\
\text { for Sustainability } \\
\text { Questionnaire, } \\
\text { SPACS-Q. }\end{array}$ & Europe & $\begin{array}{l}\text { Adolesc. } \\
(12-19)\end{array}$ & 12 & 0 & 0 & 0 & 0 & 0 & 0 & 0 & 12 & -Eco-information \\
\hline
\end{tabular}


EURASIA J Math Sci and Tech Ed

\begin{tabular}{|c|c|c|c|c|c|c|c|c|c|c|c|c|c|}
\hline Author (s) & Scale name & Reg & Level & Items & Climate & Littering & Forestry & Biodiversity & Pollution & Technology & Scarce $r$ & General & Any other \\
\hline $\begin{array}{l}\text { Mayer \& } \\
\text { Frantz (2004) }\end{array}$ & $\begin{array}{l}\text { connectedness } \\
\text { to nature scale } \\
\text { (CNS) }\end{array}$ & N. A & Adults & 14 & 0 & 0 & 1 & 3 & 0 & 0 & 0 & 10 & $\begin{array}{c}\text {-Enjoyment of } \\
\text { nature } \\
\text {-Anthropocentrism }\end{array}$ \\
\hline $\begin{array}{l}\text { Pelletier et al. } \\
(1998)\end{array}$ & $\begin{array}{l}\text { Motivation } \\
\text { Toward the } \\
\text { Environment } \\
\text { Scale (MTES). }\end{array}$ & N. A & Adults & 24 & 0 & 0 & 0 & 0 & 0 & 0 & 0 & 24 & $\begin{array}{l}\text {-Enjoyment of } \\
\text { nature }\end{array}$ \\
\hline $\begin{array}{l}\text { Martin \& } \\
\text { Czellar (2016) }\end{array}$ & $\begin{array}{l}\text { The Extended } \\
\text { Inclusion of } \\
\text { Nature in Self } \\
\text { Scale (EINS) }\end{array}$ & Europe & Adults & 4 & 0 & 0 & 0 & 0 & 0 & 0 & 0 & 4 & \\
\hline \multirow[t]{2}{*}{$\begin{array}{l}\text { Félonneau \& } \\
\text { Becker (2008) }\end{array}$} & $\begin{array}{l}\text { Pro- } \\
\text { Environmental } \\
\text { Attitudes } \\
\text { Questionnaire }\end{array}$ & Europe & & 28 & 0 & 4 & 0 & 0 & 10 & 0 & 7 & 7 & $\begin{array}{c}\text {-Green } \\
\text { consumerism } \\
\text {-Eco-information }\end{array}$ \\
\hline & $\begin{array}{l}\text { Pro- } \\
\text { Environmental } \\
\text { Behavior } \\
\text { Questionnaire }\end{array}$ & Europe & Adults & 18 & 0 & 7 & 0 & 0 & 4 & 0 & 7 & 0 & \\
\hline $\begin{array}{l}\text { Richardson et } \\
\text { al. (2019). }\end{array}$ & $\begin{array}{l}\text { Nature } \\
\text { Connection } \\
\text { Index (NCI) }\end{array}$ & Europe & $\begin{array}{l}\text { Children } \\
\text { \& adults }\end{array}$ & 6 & 0 & 0 & 0 & 0 & 0 & 0 & 0 & 6 & $\begin{array}{l}\text {-Enjoyment with } \\
\text { nature }\end{array}$ \\
\hline $\begin{array}{l}\text { Pérez- } \\
\text { Rodríguez et } \\
\text { al. (2017). }\end{array}$ & $\begin{array}{l}\text { Attitudes Scale } \\
\text { toward } \\
\text { Environmental } \\
\text { Education } \\
\text { (ASEE). }\end{array}$ & Europe & Adults & 18 & 3 & 1 & 0 & 0 & 1 & 0 & 0 & 13 & $\begin{array}{c}\text {-Green } \\
\text { consumerism } \\
\text {-Economic growth }\end{array}$ \\
\hline $\begin{array}{l}\text { Lacroix et al. } \\
\text { (2019). }\end{array}$ & $\begin{array}{l}\text { The Dragons of } \\
\text { Inaction } \\
\text { Psychological } \\
\text { Barriers (DIPB) } \\
\text { scale. }\end{array}$ & $\begin{array}{c}\text { N. } \\
\text { America }\end{array}$ & Adults & 22 & 0 & 0 & 0 & 0 & 0 & 1 & 0 & 21 & $\begin{array}{c}\text {-Social altruistic } \\
\text {-policy issues } \\
\text {-Environmental } \\
\text { activism }\end{array}$ \\
\hline $\begin{array}{l}\text { Schmidt and } \\
\text { Gifford (1989) }\end{array}$ & $\begin{array}{l}\text { The } \\
\text { Environmental } \\
\text { Appraisal } \\
\text { Inventory }\end{array}$ & $\begin{array}{c}\text { N. } \\
\text { America }\end{array}$ & Adults & 24 & 2 & 0 & 0 & 0 & 18 & 0 & 3 & 1 & Population growth \\
\hline
\end{tabular}

http://www.ejmste.com 